\title{
Use of Plant Growth Regulators for Feathering and Flower Suppression of Apple Nursery Trees
}

\author{
Jaume Lordan ${ }^{1}$ and Terence L. Robinson \\ Department of Horticulture, NYSAES, Cornell University, Geneva, NY 14456 \\ Mario Miranda Sazo \\ Cornell Cooperative Extension, Lake Ontario Fruit Program, Cornell \\ University, Newark, NY 14513
}

Win Cowgill
Rutgers Cooperative Extension, NJAES, Rutgers University, New Brunswick,
NJ 08901

Brent L. Black

Department of Plants, Soils and Climate, Utah State University, Logan, UT 84322

\section{Leslie Huffman}

Ministry of Agriculture, Food and Rural Affairs, Harrow, ON, Canada NOR $1 G 0$

\section{Kristy Grigg-McGuffin}

Ministry of Agriculture, Food and Rural Affairs, Simcoe, ON, Canada N3Y 4 N5

\section{Poliana Francescatto}

Department of Horticulture, NYSAES, Cornell University, Geneva, NY 14456

\section{Steve McArtney \\ Department of Horticulture, North Carolina State University, Fletcher, NC 28759}

Additional index words. benzyladenine, crotch angle, gibberellins, MaxCel ${ }^{\circledR}$, phytotoxicity, Promalin $^{\circledR}$

\begin{abstract}
The use of highly feathered trees can make high-density apple plantings more profitable through enhanced precocity and increased early yield. Currently, nurseries are asked to provide highly feathered trees with wide branch crotch angles. The use of plant growth regulators (PGRs) can play a key role when it comes to branch induction; however, dose and timing both need to be tested to enhance branching without compromising other tree quality attributes. Over the last 4 years, we have conducted studies of the use of $\mathrm{MaxCel}^{\circledR}$ (6-benzyladenine) and Promalin ${ }^{\circledR}$ (a mixture of $1.8 \%$ 6-benzyladenine and $1.8 \% \mathrm{GA}_{4+7}$ ) in comparison with Tiberon $^{\mathrm{TM}} \mathrm{SC}$ (cyclanilide) at several nurseries in NY, WA, DE, Ontario (Canada), and Chile. The best results were obtained with four applications of $\mathrm{MaxCel}^{\circledR}$ or Promalin ${ }^{\circledR}\left(400 \mathrm{mg} \cdot \mathrm{L}^{-1}\right)$ beginning when leader growth reached $70 \mathrm{~cm}$ above the soil line and reapplied at 10-14 days intervals. Promalin ${ }^{\circledR}$ was a slightly less effective branching agent than $\mathrm{MaxCel}^{\circledR}$. On the other hand, Promalin $^{\circledR}$ stimulated leader growth resulting in improved final tree height, whereas $\mathrm{MaxCel}^{\circledR}$ induced the widest branch angles. Overall, we observed good response and quality ratings with 'Cameo', 'Cripps Pink', 'Enterprise', 'Fuji', 'Ambrosia', 'Crimson Crisp', 'Gingergold', and 'Granny Smith', whereas less quality ratings were observed on 'Ambrosia', 'Cortland', 'Goldrush', 'Honeycrisp', and 'Suncrisp'. Response with 'Gala' varied depending on the temperature range. Multiple sprays of Gibberellins $\left(\mathrm{GA}_{4+7}\right.$, or $\mathbf{G A}_{3}$ ) at $250 \mathrm{mg} \cdot \mathrm{L}^{-1}$ applied to nursery trees in the late summer inhibited flower bud development and flowering in the orchard the next year. This reduces the risk of fire blight infection in newly planted trees.
\end{abstract}

The adoption of high-density apple orchards during the last several decades has resulted in a significant improvement in precocity, cumulative yield, and fruit quality. However, as planting density is increased, the additional benefit in yield is smaller and smaller with each additional tree (Robinson, 2008; Robinson et al., 2007). Therefore, high early yields are needed to pay back the initial investment. With the use of highly feathered trees, significant yield can be achieved in the 2nd and 3rd years after planting, which is an essential asset to help pay for increased tree numbers and establishment costs (Robinson and Stiles, 1995). As the benefits of highly feathered trees were discovered, it became necessary to develop nursery management techniques to stimulate lateral branch development. Therefore, besides large trunk caliper, nurseries are asked to provide trees with a relatively high number of short lateral branches (feathers) with wide crotch angles (Van den Berg, 2003; Weis, 2004; Wertheim and Webster, 2003). In the 1970s, leaf removal and pinching were commonly used to induce branching on nursery trees (Wertheim, 1978). In the United States, the number of feathers on grown nursery trees has improved significantly in the last decade. Before 2009, most nurseries used a single spray of Promalin ${ }^{\circledR}$ (benzyladenine $+\mathrm{GA}_{4+7}$; Valent BioSciences Corp., Libertyville, IL) combined with leaf removal to obtain trees with three-to-five feathers. In the spring of 2009, a new branching chemical, Tiberon ${ }^{\mathrm{TM}}$ SC (cyclanilide, Bayer Environmental Sciences, Research Triangle Park, NC), was registered and was used commercially in the United States, improving the quality of apple nursery trees (Elfving and Visser, 2005, 2006b). In 2012, Tiberon ${ }^{\text {TM }}$ SC was withdrawn from the market. European nurseries have been using 6-benzyladenine in the form of $\mathrm{MaxCel}^{\circledR}$ (Valent BioSciences Corp.)/Exilis (Fine Agrochemicals, Worcester, UK) or 10\% BA Paturyl (Reanal, Budapest, Hungary) to induce branching (Basak et al., 1992). $\mathrm{MaxCel}^{\circledR}$, a cytokinin plant growth regulator that is already labeled for several uses on apples, was registered for chemical branching of nursery apple trees in the United States in 2013.

Most of the published branching studies were done many years ago on varieties that are no longer grown (Basak et al., 1992; Cody et al., 1985; Forshey, 1982; Jaumien et al., 1993; Miller and Eldridge, 1986). Other studies reported notching (Greene and Autio, 1994) or a combination of notching plus hormone sprays (Greene and Miller, 1988; Mcartney and Obermiller, 2015) as a technique to increase branching. In 2010, we evaluated the use of Tiberon ${ }^{\mathrm{TM}} \mathrm{SC}$ on 'Macoun' trees in New York and found Tiberon ${ }^{\mathrm{TM}} \mathrm{SC}$ to significantly reduce tree height and caliper, resulting in poor tree architecture under Eastern climatic conditions (Miranda Sazo and Robinson, 2011). To further study the use of $\mathrm{MaxCel}^{\circledR}$ and Promalin $^{\circledR}$ in comparison with Tiberon ${ }^{\mathrm{TM}}$ SC, we have conducted 10 experiments at several nurseries in NY, WA, DE, Ontario (Canada), and Chile over the last 4 years.

Nursery-produced apple trees of many varieties bloom prolifically when subsequently planted in commercial orchards. Once trees are moved from the nursery to the orchard, new spring planted trees bloom later than established orchards when temperatures are warmer. These trees are at higher risk of blossom fire blight (Erwinia amylovora Burrill) if left unprotected or with fewer 
streptomycin sprays (Vanneste, 2000). Hence, an apple tree that doesn't flower in the 1st year after planting may be a good strategy for fire blight control. Although many studies have reported the use of hormone sprays to reduce flower induction and improve biennial bearing (Greene, 2000; Jonkers, 1979; Mcartney and Li, 1998; Unrath and Whitworth, 1991), there is a dearth of studies that focus on flower inhibition for nursery trees. A second objective of our study was to determine if gibberellin sprays in the nursery could inhibit flower bud formation thus reducing flowering the following season in the orchard to minimize the risk of fire blight.

\section{Materials and Methods}

\section{Branching induction experiments}

$P G R$ application and design. All plant growth regulator treatments were applied with manually operated Solo (425; Solo, Newport News, VA) and Shindaiwa (SP415; Shindaiwa, Lake Zurich, IL) backpack sprayers with a single nozzle directed over the leader tip of each tree, calibrated to apply $4 \mathrm{~mL}$ of solution at each application (Table 1). On the first application date, the central leader shoot tips for each budded scion were $\approx 70 \mathrm{~cm}$ above the soil. Tree height is a good criterion for branching induction through PGR applications (Elfving and Visser, 2006a, 2006b). Control trees were unsprayed.

In November (USA \& Canada), or in July (Chile), trees were measured in the nursery for: 1) trunk diameter (measured $13 \mathrm{~cm}$ above bud union), 2) length of central leader aboveground level to tip, 3) total number of feathers (any lateral shoot longer than $10 \mathrm{~cm}$ ), 4) distance from the ground level to each of the induced feathers, 5) length of each feather, and 6) crotch angle of each feather $\left(90^{\circ}=\right.$ upright, $0^{\circ}=$ flat $)$. In experiment 10 , tree quality $(1=$ poor, $5=$ excellent $)$ was subjectively assessed, taking into account the overall tree height, number of feathers, and their angle. Excellent quality trees had a tree height of 180-200 cm, and 12-15 wide-angle feathers, whereas poor quality trees were short in height and with no

Received for publication 6 Mar. 2017. Accepted for publication 19 June 2017.

This research was partially supported by the International Fruit Tree Association, the Northwest Nursery Improvement Institute, the New Jersey State Horticultural Society, and the New Jersey Agricultural Experiment Station, with additional support from the Utah Agricultural Experiment Station (Journal paper \#8959).

We thank John Baugher, Taun Beddes, Mike Beese, Shaun Calahan, Ricardo Chalhub Z., Gregory Clarke, Bill Howell, Dave Johnson, Wayne Kessinger, Bill Lawler, Rebecca Magron, and JD Obermiller for technical support and guidance. We also thank the cooperating nurseries Adams County, $\mathrm{C} \& \mathrm{O}$, Univiveros, VanWell, and Willow Drive.

The authors have declared that no competing interests exist.

${ }^{1}$ Corresponding author. E-mail: j13325@cornell. edu. feathers at all. Every experiment used a separate randomized complete block design for each cultivar with four replications (experiments 1, 3 , and 5-9), five replications (experiment 2 and 4) or 10 replications (experiment 10), distributed down a row with each experimental unit being a section of five trees (experiments $1-5$, 7,9 ) or 10 trees (experiments 6, 8, and 10).

Experiment 1: Cyclanilide, Benzyladenine $(B A)$, and BA plus $G A_{4+7}$ on 'Macoun'. A field experiment was conducted in 2012 near Ellendale, DE, where we compared the effect of summer applications of cyclanilide (Tiberon $^{\mathrm{TM}} \mathrm{SC}$; Bayer Environmental Science, Montvale, NJ), BA (MaxCel ${ }^{\circledR}$; Valent BioSciences Corp.), and BA plus $\mathrm{GA}_{4+7}$ (Promalin $^{\circledR}$, a mixture of $1.8 \% \mathrm{BA}$ and $1.8 \%$ $\mathrm{GA}_{4+7}$; Valent BioSciences Corp.) on branching. Cyclanilide was applied as a foliar spray twice at $50 \mathrm{mg} \cdot \mathrm{L}^{-1}$; whereas BA (at 500 and $1000 \mathrm{mg} \cdot \mathrm{L}^{-1}$ ) and $\mathrm{BA}$ plus $\mathrm{GA}_{4+7}$ (at 500 $\mathrm{mg} \cdot \mathrm{L}^{-1}$ ) were sprayed up to five times; all sprays were applied 2 weeks apart to standard fall budded nursery trees of 'Macoun' on 'Malling M.9T337'. All the treatments included the nonionic surfactant Regulaid ${ }^{\circledR}$ (Kalo Inc., Overland Park, KS) at $0.125 \%(\mathrm{v} / \mathrm{v})$.

Experiment 2: Cyclanilide, $B A$, and $B A$ plus $G_{4+7}$ on 'Ambrosia'. A field experiment was conducted in 2012 in Niagara, (Ontario) Canada, where we compared the effect of summer applications of cyclanilide (Tiberon $\left.^{\text {TM }} \mathrm{SC}\right), \mathrm{BA}\left(\mathrm{MaxCel}^{\circledR}\right)$, and BA plus $\mathrm{GA}_{4+7}\left(\right.$ Promalin $^{\circledR}$ ) on branching. Cyclanilide was applied as a foliar spray twice at $50 \mathrm{mg} \cdot \mathrm{L}^{-1}$; whereas BA and BA plus $\mathrm{GA}_{4+7}$ (at 500 and $1000 \mathrm{mg} \cdot \mathrm{L}^{-1}$ ) were sprayed up to four times; all sprays were applied 2 weeks apart to standard fall budded nursery trees of 'Ambrosia' on 'Budagovsky 9'. All the treatments included the nonionic surfactant Regulaid $^{\circledR}$ at $0.125 \%(\mathrm{v} / \mathrm{v})$.

Experiment 3: Cyclanilide, $B A$, and $B A$ plus $G_{4+7}$ on 'Fuji' and 'Gala'. An experiment was conducted in 2012 at Quincy, WA, where we compared the number of BA or BA plus $\mathrm{GA}_{4+7}$ sprays in comparison with one spray of cyclanilide on branching on apple nursery trees. Proprietary formulations of cyclanilide $\left(\right.$ Tiberon $\left.^{\mathrm{TM}} \mathrm{SC}\right), \mathrm{BA}\left(\mathrm{MaxCel}^{\circledR}\right)$, and BA plus $\mathrm{GA}_{4+7}\left(\right.$ Promalin $\left.^{\circledR}\right)$ were used in the trial. Cyclanilide was sprayed a single time at $100 \mathrm{mg} \cdot \mathrm{L}^{-1}$ whereas BA or BA plus $\mathrm{GA}_{4+7}$ were applied at 500 and $1000 \mathrm{mg} \cdot \mathrm{L}^{-1}$ either two, three, four, or five times, 2 weeks apart to standard fall budded nursery trees of 'Fuji'/'M.9Nic9' and 'Gala'/'M.9Nic9'. All the treatments included Regulaid ${ }^{\circledR}$ at $0.125 \%$ $(\mathrm{v} / \mathrm{v})$ as a surfactant.

Experiment 4: $B A$ and $B A$ plus $G A_{4+7}$ on 'Fuji', 'Gala', and 'Granny Smith'. An experiment was conducted in the spring of 2012 at a nursery located near Santiago, Chile, to determine the effect of $\mathrm{BA}$ plus $\mathrm{GA}_{4+7}$ $\left(\right.$ Promalin $\left.^{\circledR}\right)$ and BA $\left(\mathrm{Cylex}^{\circledR}\right.$; Valent BioSciences) on branching on three apple cultivars. BA plus $\mathrm{GA}_{4+7}$ at one rate $\left(800 \mathrm{mg} \cdot \mathrm{L}^{-1}\right)$ and $\mathrm{BA}$ at three rates $(500,750$, and 1000 $\mathrm{mg} \cdot \mathrm{L}^{-1}$ ) were applied one, two, three, four, or five times 2 weeks apart to standard fall budded nursery trees of 'Fuji'/'M.9T337',
'Gala'/'M.9T337', and 'Granny Smith'/ 'M.9T337'. All the treatments included Regulaid $^{\circledR}$ at $0.125 \%(\mathrm{v} / \mathrm{v})$ as a surfactant.

Experiment 5: Cyclanilide, $B A$, and $B A$ plus $G_{4+7}$ on 'Golden Delicious'. A field experiment was conducted in 2012 near Ellendale, DE, comparing the effect of summer sprays of cyclanilide (Tiberon ${ }^{\mathrm{TM}} \mathrm{SC}$ ), BA $\left(\mathrm{MaxCel}^{\circledR}\right)$, and BA plus $\mathrm{GA}_{4+7}\left(\right.$ Promalin $\left.^{\circledR}\right)$ on branching on 'Golden Delicious'/'M.9T337'. Cyclanilide was sprayed one time at $100 \mathrm{mg} \cdot \mathrm{L}^{-1}$, or two times at $50 \mathrm{mg} \cdot \mathrm{L}^{-1}$; whereas BA (at 500 and $1000 \mathrm{mg} \cdot \mathrm{L}^{-1}$ ) and $\mathrm{BA}$ plus $\mathrm{GA}_{4+7}$ $\left(500 \mathrm{mg} \cdot \mathrm{L}^{-1}\right)$ were sprayed either two, four, or five times, 2 weeks apart. All the treatments included Regulaid ${ }^{\circledR}$ at $0.125 \%(\mathrm{v} / \mathrm{v})$ as a surfactant.

Experiment 6: Cyclanilide, $B A$, and $B A$ plus $G A_{4+7}$ on 'Fuji'. A field experiment was conducted in 2013 at Ellendale, DE, where we compared the effect of summer sprays of cyclanilide (Tiberon $\left.{ }^{\mathrm{TM}}, \mathrm{SC}\right), \mathrm{BA}\left(\mathrm{MaxCel}^{\circledR}\right)$, and BA plus $\mathrm{GA}_{4+7}\left(\right.$ Promalin $\left.^{\circledR}\right)$ on branching on 'Fuji'/'M.9T337'. The experiment was designed to evaluate the effect of additional surfactant Regulaid $^{\circledR}$ to the BA treatments. Cyclanilide was sprayed two times at $50 \mathrm{mg} \cdot \mathrm{L}^{-1}$ ; BA was sprayed two to four times at 300, 400, and $500 \mathrm{mg} \cdot \mathrm{L}^{-1}$; and $\mathrm{BA}$ plus $\mathrm{GA}_{4+7}$ was sprayed four times at $500 \mathrm{mg} \cdot \mathrm{L}^{-1}$. All treatments were sprayed at $10-\mathrm{d}$ intervals. Treatments with four sprays of $\mathrm{MaxCel}^{\circledR}$ at 300, 400, and $500 \mathrm{mg} \cdot \mathrm{L}^{-1}$ were sprayed with and without Regulaid $^{\circledR}$ at $0.125 \%(\mathrm{v} / \mathrm{v})$ as a surfactant.

Experiment 7: $B A$ and $B A$ plus $G A_{4+7}$ on 'Macoun'. An experiment was conducted in 2013 near Ellendale, DE, to determine the effect of BA ( $\mathrm{MaxCel}^{\circledR}$ ) and BA plus $\mathrm{GA}_{4+7}$ $\left(\right.$ Promalin $^{\circledR}$ ) on branching of 'Macoun' apple nursery trees. Three rates of BA and BA plus $\mathrm{GA}_{4+7}\left(300,400\right.$ or $\left.500 \mathrm{mg} \cdot \mathrm{L}^{-1}\right)$ with and without Regulaid ${ }^{\circledR}$ were applied four times at 10-d intervals to standard fall budded nursery trees of 'Macoun'/‘M.9T337'. Regulaid ${ }^{\circledR}$ was added at $0.125 \%(\mathrm{v} / \mathrm{v})$.

Experiment 8: Cyclanilide, $B A$, and $B A$ plus $G A_{4+7}$ on 'Fuji' and 'Gala'. An experiment was conducted in 2013 at Quincy, WA, where we compared the number of BA or BA plus $\mathrm{GA}_{4+7}$ sprays in comparison with one spray of cyclanilide on branching on apple nursery trees. Proprietary formulations of cyclanilide $\left(\right.$ Tiberon $\left.^{\text {TM }} \mathrm{SC}\right), \mathrm{BA}\left(\mathrm{MaxCel}^{\circledR}\right)$, and BA plus $\mathrm{GA}_{4+7}\left(\right.$ Promalin $\left.^{\circledR}\right)$ were used in the trial. Cyclanilide was sprayed a single time at $100 \mathrm{mg} \cdot \mathrm{L}^{-1}$, whereas BA or BA plus $\mathrm{GA}_{4+7}$ were applied at 500 and $750 \mathrm{mg} \cdot \mathrm{L}^{-1}$ either one, two, three, or four times, 2 weeks apart to standard fall budded nursery trees of 'Fuji'/'M.9T337' and 'Gala'/'M.9T337'. All the treatments included Regulaid ${ }^{\circledR}$ at $0.125 \%$ $(\mathrm{v} / \mathrm{v})$ as a surfactant.

Experiment 9: $B A$ and $B A$ plus $\mathrm{GA}_{4+7}$ on 'Fuji'. An experiment was conducted in 2014 near Ellendale, DE, to determine the effect of the number of BA and BA plus $\mathrm{GA}_{4+7}$ sprays on branching of 'Fuji' apple nursery trees. Two application rates (400 and $\left.500 \mathrm{mg} \cdot \mathrm{L}^{-1}\right)$ for both BA plus $\mathrm{GA}_{4+7}\left(\operatorname{Promalin}^{\circledR}\right)$ and BA $\left(\mathrm{MaxCel}^{\circledR}\right)$ were applied four or five times 2 weeks apart to standard fall budded nursery 
Table 1. List of experiment number, year, location, variety, treatments [MaxCel ${ }^{\circledR}$, Promalin ${ }^{\circledR}$, Tiberon ${ }^{\mathrm{TM}} \mathrm{SC}$, and Cylex ${ }^{\circledR}$ rates are in $\mathrm{mg} \cdot \mathrm{L}^{-1} ; \mathrm{Regulaid}^{\circledR}$ at $0.125 \%$ $(\mathrm{v} / \mathrm{v})]$, and timing within sprays performed for the different branching induction trials.

\begin{tabular}{|c|c|c|c|c|c|}
\hline Expt. \# & Yr & Location & Variety & Treatments & Timing between sprays \\
\hline 2 & 2012 & Niagara, ON, Canada & Ambrosia & $\begin{array}{l}\text { MaxCe11000 } 2 \times+ \text { Regulaid } \\
\text { MaxCel1000 } 4 \times+ \text { Regulaid } \\
\text { MaxCel500 } 2 \times+ \text { Regulaid } \\
\text { MaxCel500 } 4 \times+ \text { Regulaid } \\
\text { Promalin500 } 2 \times+ \text { Regulaid } \\
\text { Promalin500 } 4 \times+ \text { Regulaid } \\
\text { Tiberon50 } 2 \times+ \text { Regulaid } \\
\text { Untreated }\end{array}$ & 2 weeks apart \\
\hline 3 & 2012 & Quincy, WA & $\begin{array}{l}\text { Fuji } \\
\text { Gala }\end{array}$ & $\begin{array}{l}\text { MaxCel500 } 2 \times+ \text { Regulaid } \\
\text { MaxCel500 } 3 \times+ \text { Regulaid } \\
\text { MaxCel500 } 4 \times+ \text { Regulaid } \\
\text { MaxCel500 5x+ Regulaid } \\
\text { MaxCel1000 } 2 \times+ \text { Regulaid } \\
\text { MaxCel1000 } 3 \times+ \text { Regulaid } \\
\text { MaxCel1000 } 4 \times+ \text { Regulaid } \\
\text { MaxCel1000 } 5 \times+ \text { Regulaid } \\
\text { Promalin500 } 2 \times+ \text { Regulaid } \\
\text { Promalin500 } 3 \times+ \text { Regulaid } \\
\text { Promalin500 } 4 \times+ \text { Regulaid } \\
\text { Promalin500 } 5 \times+ \text { Regulaid } \\
\text { Tiberon100 } 1 \times+ \text { Regulaid } \\
\text { Untreated }\end{array}$ & 2 weeks apart \\
\hline 4 & 2012 & Santiago de Chile, Chile & $\begin{array}{l}\text { Fuji } \\
\text { Gala } \\
\text { Granny Smith }\end{array}$ & 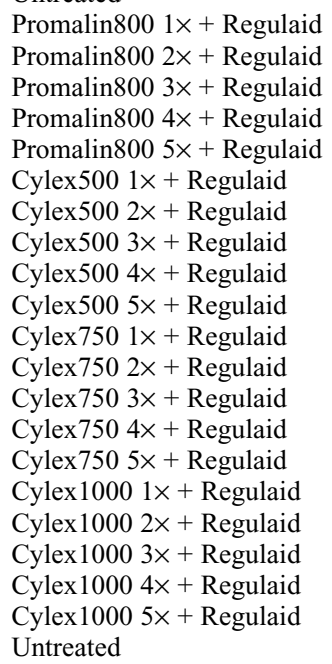 & 2 weeks apart \\
\hline 5 & 2012 & Ellendale, DE & Golden Delicious & $\begin{array}{l}\text { MaxCel1000 } 2 \times+ \text { Regulaid } \\
\text { MaxCel1000 } 4 \times+ \text { Regulaid } \\
\text { MaxCel1000 5x+ Regulaid } \\
\text { MaxCel500 } 2 \times+ \text { Regulaid } \\
\text { MaxCel500 } 4 \times+ \text { Regulaid } \\
\text { MaxCel500 } 5 \times+ \text { Regulaid } \\
\text { Promalin500 } 2 \times+ \text { Regulaid } \\
\text { Promalin500 } 4 \times+ \text { Regulaid } \\
\text { Tiberon100 } 1 \times+ \text { Regulaid } \\
\text { Tiberon50 } 2 \times+ \text { Regulaid } \\
\text { Untreated }\end{array}$ & 2 weeks apart \\
\hline 6 & 2013 & Ellendale, DE & Fuji & $\begin{array}{l}\text { MaxCe1300 4× } \\
\text { MaxCe1300 4× + Regulaid } \\
\text { MaxCe1400 3× } \\
\text { MaxCe1400 4× } \\
\text { MaxCe1400 4× + Regulaid } \\
\text { MaxCe1500 2× } \\
\text { MaxCe1500 3× } \\
\text { MaxCe1500 4× } \\
\text { MaxCe1500 4× + Regulaid } \\
\text { Promalin500 4× } \\
\text { Tiberon50 2× } \\
\text { Untreated }\end{array}$ & 10-d intervals \\
\hline 7 & 2013 & Ellendale, DE & Macoun & $\begin{array}{l}\text { MaxCel300 4× } \\
\text { MaxCel300 4× + Regulaid }\end{array}$ & 10-d intervals \\
\hline
\end{tabular}


Table 1. (Continued) List of experiment number, year, location, variety, treatments [MaxCel ${ }^{\circledR}$, Promalin ${ }^{\circledR}$, Tiberon ${ }^{\mathrm{TM}} \mathrm{SC}$, and $\mathrm{Cylex}^{\circledR}$ rates are in mg. $\mathrm{L}^{-1}$; Regulaid $^{\circledR}$ at $\left.0.125 \%(\mathrm{v} / \mathrm{v})\right]$, and timing within sprays performed for the different branching induction trials.

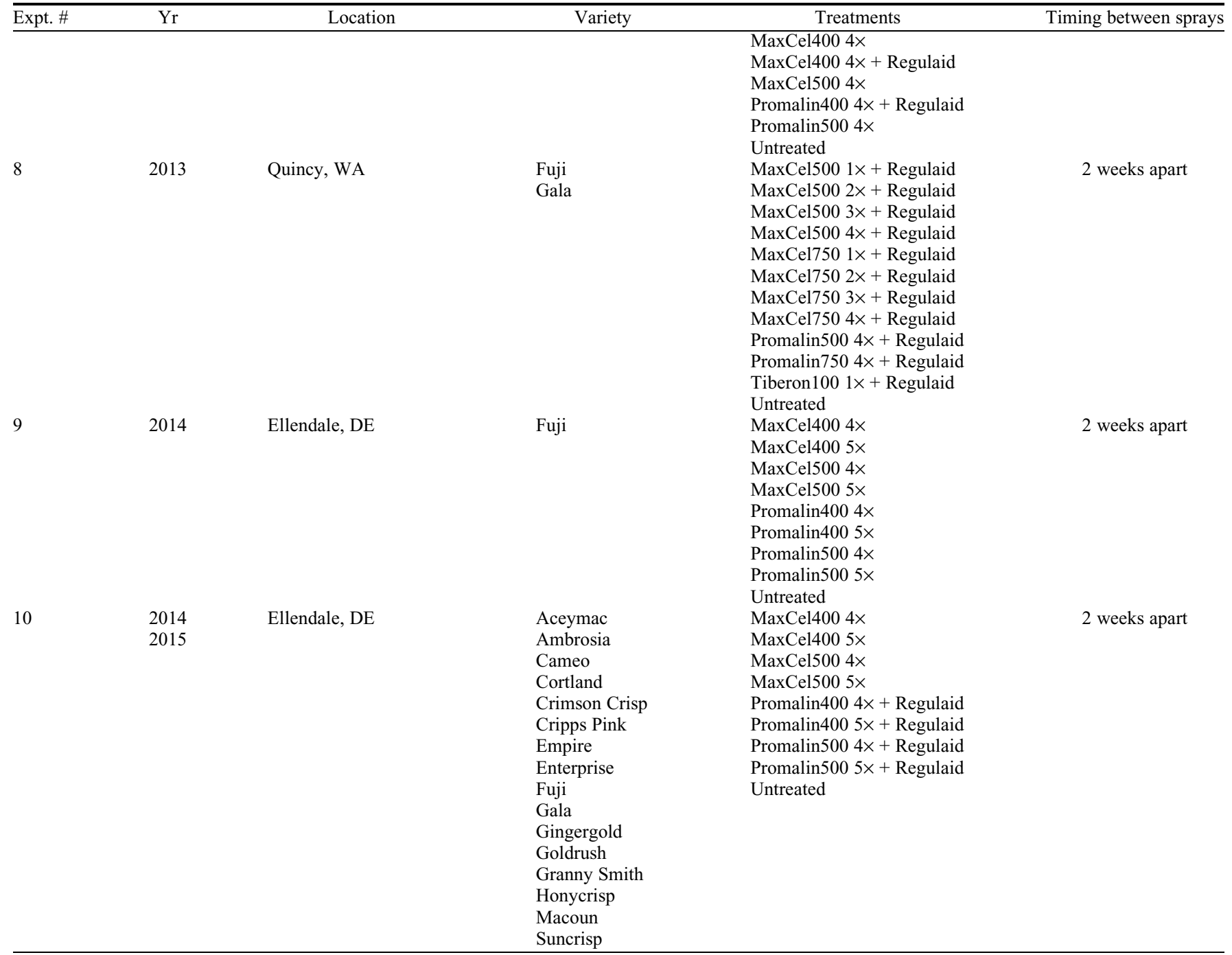

trees of 'Daybreak Fuji'/‘M.9T337'. All the Promalin $^{\circledR}$ applications included Regulaid ${ }^{\circledR}$ at $0.125 \%(\mathrm{v} / \mathrm{v})$ as a surfactant.

Experiment 10: $B A$ and $B A$ plus $G A_{4+7}$ on a range of varieties. Two trials were conducted in 2014 and 2015 near Ellendale, $\mathrm{DE}$, to determine the effect of BA (MaxCel $\left.{ }^{\circledR}\right)$ and BA plus $\mathrm{GA}_{4+7}\left(\right.$ Promalin $\left.^{\circledR}\right)$ sprays on branching of a range of varieties. For both years all Promalin ${ }^{\circledR}$ treatments included Regulaid $^{\circledR}$ at $0.125 \%$ (v/v) as a surfactant, whereas $\mathrm{MaxCe}^{\circledR}$ treatments did not include any surfactant. In 2014, $\mathrm{MaxCel}^{\circledR}$ at $400 \mathrm{mg} \cdot \mathrm{L}^{-1}$ and Promalin ${ }^{\circledR}$ at 400 and $500 \mathrm{mg} \cdot \mathrm{L}^{-1}$; and in 2015, MaxCel ${ }^{\circledR}$ at 400 and $500 \mathrm{mg} \cdot \mathrm{L}^{-1}$ and Promalin $^{\circledR}$ at $500 \mathrm{mg} \cdot \mathrm{L}^{-1}$ were applied five times 2 weeks apart to standard fall budded nursery trees of 'Aceymac'/'M.9T337', 'Ambrosia'/‘M.9T337', 'Cameo'/‘M.9T337', 'Crimson Crisp'/‘M.9T337', 'Cripps Pink'/ 'M.9T337', 'Empire'/‘M.9T337', 'Enterprise'/ 'M.9T337', 'Aztec Fuji'/'M.9T337', 'Ultima Gala'/'M.9T337', 'Gingergold'/'M.9T337', 'Goldrush'/'M.9T337', 'Granny Smith'/ 'M.9T337', 'Honeycrisp'/‘M.9T337', 'Honeycrisp Premier'/‘M.9T337' 'Macoun'/‘M.9T337', and 'Royal Court - Cortland'/'M.9T337'. In
2015, $\mathrm{MaxCel}^{\circledR}$ at 200, 300, and $400 \mathrm{mg} \cdot \mathrm{L}^{-1}$ only with no surfactant was applied five times 2 weeks apart for 'Suncrisp'/‘M.9T337'.

\section{Flower inhibition experiment}

Experiment 11: Inhibition of flowering. An experiment was conducted in Ephrata, WA, in the late summer of 2013 to inhibit the formation of flower buds in the nursery, which would reduce flowering in the first year in the orchard. $\mathrm{GA}_{3}$ at two rates (100 and $\left.250 \mathrm{mg} \cdot \mathrm{L}^{-1}\right)$ and $\mathrm{GA}_{4+7}$ at $250 \mathrm{mg} \cdot \mathrm{L}^{-1}$ were sprayed two, three, or four times to 'Pink Lady'/'M.9T337' and 'Gala'/'M.9T337' apple trees every $14 \mathrm{~d}$, starting on 15 July.

The trees were dug in Nov. 2013 and kept in commercial cold storage through the winter; then planted at Geneva, NY ('Gala'), Payson, UT ('Gala'), and Mills River, NC ('Pink Lady'), in the spring of 2014. At full bloom the number of flower clusters per tree was counted.

\section{Weather data}

Daily climatic variables such as maximum temperature (Max, $\left.{ }^{\circ} \mathrm{C}\right)$, minimum temperature (Min, ${ }^{\circ} \mathrm{C}$ ), and relative humidity $(\mathrm{RH}, \%)$ were obtained from the closest automatic weather station for Quincy, WA, in 2012-13 (Experiments 3 and 8), Chile 2012 (Experiment 4), Ellendale, DE, 2014 (Experiment 9), Geneva. NY. 2014 (Experiment 11), and Payson, UT, 2014 (Experiment 11) (Fig. 1).

\section{Data analysis}

Each site/experiment was analyzed individually. Response variables for both branching induction and flower inhibition experiments were modeled using linear mixed effect models. Mixed models including treatment as fixed factor and block as a random factor were built to separate treatment effects. For all the models, when the main effect (treatment) was significant, comparisons among treatments were made by Tukey's honest significant difference test at $P$ values $\leq 0.05$. Residual analysis was performed to ensure that model assumptions were met. Data were analyzed using the JMP statistical software package (Version 12; SAS Institute Inc., Cary, NC).

\section{Results}

Experiment 1: Cyclanilide, $B A$, and $B A$ plus $G_{A 4+7}$ on 'Macoun' in 2012 in DE. Smaller trunk cross sectional area (TCSA) 

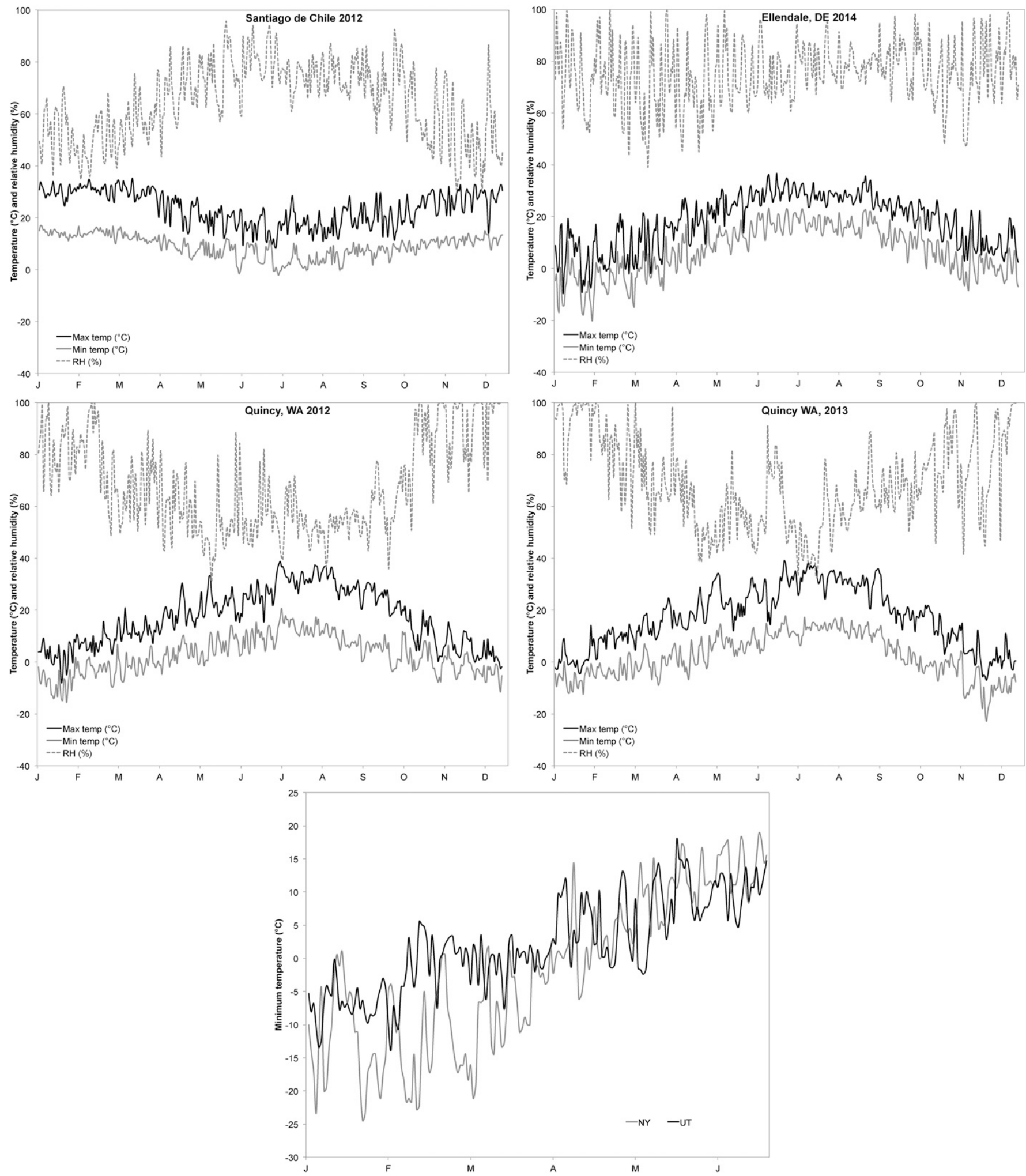

Fig. 1. Average daily maximum and minimum temperature $\left({ }^{\circ} \mathrm{C}\right)$ and relative humidity $(\mathrm{RH}, \%)$ for Santiago de Chile 2012 (Experiment 4 ), Quincy, WA, $2012-13$ (Experiments 3 and 8), and Ellendale, DE, 2014 (Experiment 9). Bottom chart represents average daily minimum temperature $\left({ }^{\circ} \mathrm{C}\right)$ for Geneva, $\mathrm{NY}$, and Payson, UT, in 2014 (Experiment 11).

values were observed on Tiberon ${ }^{\mathrm{TM}} \mathrm{SC}$ sprayed-trees, whereas no significant differences were observed among $\mathrm{MaxCel}^{\circledR}$ or Promalin ${ }^{\circledR}$ sprays or the untreated control (Table 2). Final height and height increase was lower on Tiberon ${ }^{\mathrm{TM}}$ SC sprayed-trees, higher on Promalin ${ }^{\circledR}$, with no differences between $\mathrm{MaxCel}{ }^{\circledR}$ sprayedtrees and control trees. Phytotoxicity was very low with all the treatments except trees sprayed with Tiberon ${ }^{\mathrm{TM}} \mathrm{SC}$ which had higher amounts of phytotoxicity. On those trees, high phytotoxicity was observed on the growing tips, along the leader where there was twisting, and some thickening or swelling of the tissues.

The untreated trees had the fewest number of branches per tree ( 2.3 branches per tree), followed by the Tiberon ${ }^{\top \mathrm{M}}$ SC-sprayed (5.6) treatments and then both $\mathrm{MaxCel}^{\circledR}$ and Promalin $^{\circledR}$ treatments $(>8.9)$ with higher 
number of feathers originating farther up the tree. Both MaxCel ${ }^{\circledR}$ and Promalin ${ }^{\circledR}$ also induced wider branch angles, and increasing the dose significantly reduced the shoot angle (flatter) as well. Shorter lateral shoots were observed on the treatments that had greater shoot number.

Experiment 2: Cyclanilide, $B A$, and $B A$ plus $\mathrm{GA}_{4+7}$ on 'Ambrosia' in 2012 in Ontario. No significant differences were observed regarding TCSA on 'Ambrosia' trees (Table 3). The highest TCSA increase was observed with two applications of Promalin ${ }^{\circledR}$ at 500 $\mathrm{mg} \cdot \mathrm{L}^{-1}$, whereas the lowest was observed when applying four sprays of $\mathrm{MaxCel}^{\circledR}$ at $1000 \mathrm{mg} \cdot \mathrm{L}^{-1}$. Tree height and height increase were greatest on untreated and Promalin ${ }^{\circledR}$ sprayed-trees, whereas they were reduced when increasing the dose and number of sprays of MaxCel ${ }^{\circledR}$. More shoots were observed when applying $\mathrm{MaxCel}^{\circledR}$ at 1000 $\mathrm{mg} \cdot \mathrm{L}^{-1}$, followed by $\mathrm{MaxCel}^{\circledR}$ at $500 \mathrm{mg} \cdot \mathrm{L}^{-1}$, Promalin $^{\circledR}$ at $500 \mathrm{mg} \cdot \mathrm{L}^{-1}$, Tiberon ${ }^{\mathrm{TM}} \mathrm{SC}$, and lastly the untreated trees. Untreated trees had longer shoots at a lower average height. Narrower crotch angles were observed when Tiberon $^{\mathrm{TM}} \mathrm{SC}$ was applied.

Experiment 3: Cyclanilide, BA, and BA plus $G_{4+7}$ on 'Fuji' and 'Gala' in 2012 in WA. No significant differences were observed in TCSA on either 'Fuji' or 'Gala' trees among the different treatments in this study (Table 4).

On 'Fuji', even though no significant differences in tree height were observed among the different treatments, there was a tendency for reduced tree height with increasing dose and number of $\mathrm{MaxCel}^{\circledR}$ sprays. Number of shoots was significantly increased up to four times more with increasing rate and the number of sprays $\left(\mathrm{MaxCel}^{\circledR} 1000 \mathrm{mg} \cdot \mathrm{L}^{-1}\right.$ four to five sprays and Promalin ${ }^{\circledR} 500 \mathrm{mg} \cdot \mathrm{L}^{-1}$ five sprays). Average shoot height tended to be higher on untreated trees, followed by Promalin ${ }^{\circledR}$ sprayed-trees, and then $\mathrm{MaxCel}^{\circledR}$ and Tiberon $^{\mathrm{TM}} \mathrm{SC}$ with the lowest average shoot height. Compared with the control, lateral shoot length was only increased with either $\mathrm{MaxCel}^{\circledR}$ sprayed-trees or Promalin ${ }^{\circledR}$ sprayedtrees three times. On 'Gala', unsprayed trees had similar height as the ones sprayed with Promalin ${ }^{\circledR}$, whereas trees sprayed with MaxCel ${ }^{\circledR}$ four to five times were shorter. There was a tendency to increase the number of lateral shoots when increasing the number of sprays of $\mathrm{MaxCel}^{\circledR}$, but with 'Gala', no treatment was significantly different from the untreated control. No significant differences were observed regarding the height or length of the feathers among untreated and PGR sprayed-trees with 'Gala'.

Experiment 4: BA and BA plus $G A_{4+7}$ on 'Fuji', 'Gala', and 'Granny Smith' in 2012 in Chile. Leader growth followed a sigmoidal curve throughout the season, with the greatest growth rate on the date of the first application (Fig. 2). Higher growth rates were observed for 'Fuji', followed with similar values by 'Gala' and 'Granny Smith'. About 3-4 weeks after the first application, growth rate was higher on Promalin ${ }^{\circledR}$ sprayed-trees than the control, whereas a slight decrease in growth rate compared with the control was observed when Cylex ${ }^{\circledR}$ was applied.

Both Cylex ${ }^{\circledR}$ and Promalin ${ }^{\circledR}$ induced significant greater numbers of feathers in all varieties than the untreated controls which had an average slightly more than three feathers per tree (Fig. 3). With 'Fuji' and 'Granny Smith', the best treatments produced slightly more than 13 feathers, whereas with 'Gala', the best treatments produced about 10-12 feathers. With Cylex ${ }^{\circledR}$, a double spray produced an intermediate feathering response in 'Fuji' and 'Granny Smith' and less feathering response in 'Gala'. The greatest number of feathers with Cylex ${ }^{\circledR}$ was obtained with four sprays of $750 \mathrm{mg} \cdot \mathrm{L}^{-1}$ for 'Granny Smith', 'Fuji', and 'Gala'. With Promalin ${ }^{\circledR}$, four sprays of $800 \mathrm{mg} \cdot \mathrm{L}^{-1}$ gave the greatest number of feathers for 'Fuji', 'Gala', and 'Granny Smith'. No significant differences among treatments were observed within the same number of applications. A fifth spray of Promalin ${ }^{\circledR}$ at $800 \mathrm{mg} \cdot \mathrm{L}^{-1}$ or Cylex ${ }^{\circledR}$ either at 500,750 , or $1000 \mathrm{mg} \cdot \mathrm{L}^{-1}$ did not increase the number of feathers, indicating that only four sprays were needed for maximum branching.

Feather length of untreated trees was greatest for 'Fuji', followed by 'Gala' and 'Granny Smith' (Fig. 3). Promalin ${ }^{\circledR}$ sprays increased the length of feathers of all cultivars. Feather length had a slight negative correlation with the number of applications of Cylex ${ }^{\circledR}$. The greatest reduction in feather length was produced for 'Gala' with five sprays of Cylex ${ }^{\circledR}$ at $750 \mathrm{mg} \cdot \mathrm{L}^{-1}$.

Experiment 5: Cyclanilide, $B A$, and $B A$ plus $\mathrm{GA}_{4+7}$ on 'Golden Delicious' in 2012 in $D E$. No differences in TCSA were observed, whereas tree height was significantly reduced when applying Tiberon ${ }^{\mathrm{TM}}$ SC (Table 5). Doubling MaxCel ${ }^{\circledR}$ dose to $1000 \mathrm{mg} \cdot \mathrm{L}^{-1}$ tended to reduce tree height when compared with either

Table 2. Effects of various plant growth regulator treatments sprayed two or five times $(2 \times, 5 \times)$ at 50,500 , or 1000 mg. $\mathrm{L}^{-1}$ on 'Macoun' apple trees in Ellendale, DE, in 2012 (Experiment 1). All the treatments included Regulaid ${ }^{\circledR}$ at $0.125 \%(\mathrm{v} / \mathrm{v})$ as a surfactant. Shoot height from ground is the distance from the ground level to each of the induced feathers.

\begin{tabular}{|c|c|c|c|c|c|c|c|c|c|}
\hline Treatment & $\operatorname{TCSA}\left(\mathrm{cm}^{2}\right)$ & $\begin{array}{c}\text { TCSA } \\
\text { increase }\left(\mathrm{cm}^{2}\right)\end{array}$ & $\mathrm{Ht}(\mathrm{cm})$ & Ht increase $(\mathrm{cm})$ & $\begin{array}{l}\text { Phytotoxicity } \\
(1=\text { none, } \\
10=\text { severe })\end{array}$ & $\begin{array}{l}\text { Shoot } \\
\text { number }\end{array}$ & $\begin{array}{l}\text { Shoot ht from } \\
\text { ground }(\mathrm{cm})\end{array}$ & $\begin{array}{c}\text { Shoot } \\
\text { angle (degrees) }\end{array}$ & Shoot length $(\mathrm{cm})$ \\
\hline MaxCel1000 5x & $2.3 \mathrm{ab}$ & $1.5 \mathrm{ab}$ & $163 \mathrm{bc}$ & $61 \mathrm{~b}$ & $0.2 \mathrm{~b}$ & $10 \mathrm{a}$ & $41 \mathrm{~b}$ & $43 \mathrm{c}$ & $8 \mathrm{~b}$ \\
\hline MaxCel500 5x & $2.4 \mathrm{a}$ & $1.6 \mathrm{ab}$ & $169 \mathrm{~b}$ & $64 \mathrm{~b}$ & $0.0 \mathrm{~b}$ & $9 \mathrm{a}$ & $43 \mathrm{ab}$ & $48 \mathrm{~b}$ & $8 \mathrm{~b}$ \\
\hline Promalin500 $5 \times$ & $2.5 \mathrm{a}$ & $1.7 \mathrm{ab}$ & $178 \mathrm{a}$ & $77 \mathrm{a}$ & $0.0 \mathrm{~b}$ & $9 \mathrm{a}$ & $43 \mathrm{a}$ & $49 \mathrm{~b}$ & $8 \mathrm{~b}$ \\
\hline Tiberon50 $2 \times$ & $2.1 \mathrm{~b}$ & $1.3 \mathrm{~b}$ & $152 \mathrm{~d}$ & $52 \mathrm{c}$ & $1.3 \mathrm{a}$ & $6 \mathrm{~b}$ & $35 \mathrm{c}$ & $54 \mathrm{a}$ & $15 \mathrm{a}$ \\
\hline Untreated & $2.2 \mathrm{ab}$ & $1.5 \mathrm{ab}$ & $160 \mathrm{c}$ & $59 \mathrm{~b}$ & $0.0 \mathrm{~b}$ & $2 \mathrm{c}$ & $36 \mathrm{c}$ & $57 \mathrm{a}$ & $14 \mathrm{a}$ \\
\hline$P$ & 0.0085 & 0.0095 & $<0.0001$ & $<0.0001$ & $<0.0001$ & $<0.0001$ & $<0.0001$ & $<0.0001$ & $<0.0001$ \\
\hline
\end{tabular}

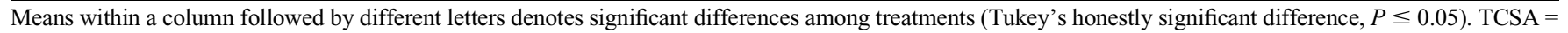
trunk cross sectional area.

Table 3. Effects of various plant growth regulator treatments sprayed two or four times (2×, $4 \times)$ at 50,500 , or 1000 mg. $\mathrm{L}^{-1}$ on 'Ambrosia' apple trees in Ontario, Canada, in 2012 (Experiment 2). All the treatments included Regulaid ${ }^{\circledR}$ at $0.125 \%(\mathrm{v} / \mathrm{v})$ as a surfactant. Shoot height from ground is the distance from the ground level to each of the induced feathers.

\begin{tabular}{|c|c|c|c|c|c|c|c|c|}
\hline Treatment & $\operatorname{TCSA}\left(\mathrm{cm}^{2}\right)$ & $\begin{array}{c}\text { TCSA } \\
\text { increase }\left(\mathrm{cm}^{2}\right)\end{array}$ & $\mathrm{Ht}(\mathrm{cm})$ & $\begin{array}{l}\text { Ht increase } \\
(\mathrm{cm})\end{array}$ & Shoot number & $\begin{array}{l}\text { Shoot ht } \\
\text { from ground }(\mathrm{cm})\end{array}$ & $\begin{array}{c}\text { Shoot angle } \\
\text { (degrees) }\end{array}$ & $\begin{array}{c}\text { Shoot } \\
\text { length }(\mathrm{cm})\end{array}$ \\
\hline MaxCel1000 2x & 1.19 & $1.0 \mathrm{ab}$ & $106 \mathrm{de}$ & $37 \mathrm{~d}$ & $6 a$ & $63 \mathrm{a}$ & $36 \mathrm{~cd}$ & $14 \mathrm{c}$ \\
\hline MaxCel1000 4x & 1.16 & $0.9 \mathrm{~b}$ & $103 \mathrm{e}$ & $34 \mathrm{~d}$ & $5 \mathrm{a}$ & $61 \mathrm{a}$ & $35 \mathrm{~d}$ & $14 \mathrm{c}$ \\
\hline MaxCel500 2x & 1.27 & $1.0 \mathrm{ab}$ & $113 \mathrm{bc}$ & $43 \mathrm{bc}$ & $4 \mathrm{~b}$ & $66 \mathrm{a}$ & $42 \mathrm{~b}$ & $14 \mathrm{c}$ \\
\hline MaxCel500 4× & 1.22 & $1.0 \mathrm{ab}$ & $109 \mathrm{~cd}$ & $45 \mathrm{~b}$ & $3 \mathrm{~b}$ & $60 \mathrm{a}$ & $42 \mathrm{bc}$ & $14 \mathrm{c}$ \\
\hline Promalin500 $2 \times$ & 1.30 & $1.1 \mathrm{a}$ & $120 \mathrm{a}$ & $51 \mathrm{a}$ & $1 \mathrm{c}$ & $64 \mathrm{a}$ & $43 \mathrm{bc}$ & $18 \mathrm{bc}$ \\
\hline Promalin500 $4 \times$ & 1.21 & $1.0 \mathrm{ab}$ & $118 \mathrm{ab}$ & $51 \mathrm{a}$ & $1 \mathrm{c}$ & $62 \mathrm{a}$ & $45 \mathrm{~b}$ & $20 \mathrm{~b}$ \\
\hline Tiberon50 $2 \times$ & 1.25 & $1.0 \mathrm{ab}$ & 108 cde & $39 \mathrm{~cd}$ & $1 \mathrm{c}$ & $61 \mathrm{a}$ & $53 \mathrm{a}$ & $14 \mathrm{c}$ \\
\hline Untreated & 1.29 & $1.1 \mathrm{ab}$ & $121 \mathrm{a}$ & $54 \mathrm{a}$ & $0 \mathrm{c}$ & $41 \mathrm{~b}$ & $49 \mathrm{ab}$ & $29 \mathrm{a}$ \\
\hline$P$ & NS & 0.0297 & $<0.0001$ & $<0.0001$ & $<0.0001$ & 0.0002 & $<0.0001$ & $<0.0001$ \\
\hline
\end{tabular}

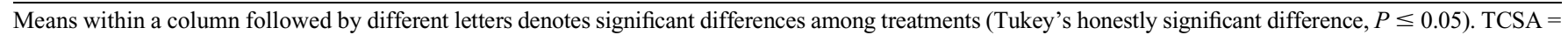
trunk cross sectional area; $\mathrm{NS}=$ nonsignificant at $P \leq 0.05$. 
Table 4. Effects of $\mathrm{MaxCel}^{\circledR}$ (Max), Promalin ${ }^{\circledR}$ (Prom), or Tiberon ${ }^{\text {TM }} \mathrm{SC}$ (Tib) treated two to five times ( $2 \times$ to $\left.5 \times\right)$ at 100,500 , or $1000 \mathrm{mg} \cdot \mathrm{L}^{-1}$ on 'Fuji' and 'Gala' apple trees in the nursery at Quincy, WA, in 2012 (Experiment 3). All the treatments included Regulaid ${ }^{\circledR}$ at $0.125 \%$ (v/v) as a surfactant. Shoot height from ground is the distance from the ground level to each of the induced feathers.

\begin{tabular}{|c|c|c|c|c|c|c|}
\hline Variety & Treatment & $\operatorname{TCSA}\left(\mathrm{cm}^{2}\right)$ & $\mathrm{Ht}(\mathrm{cm})$ & Shoot number & Shoot ht from ground $(\mathrm{cm})$ & Shoot length $(\mathrm{cm})$ \\
\hline \multirow[t]{11}{*}{ Fuji } & Max500 2x & 1.5 & $175 \mathrm{ab}$ & $8 \mathrm{fg}$ & 84 ef & $41 \mathrm{abc}$ \\
\hline & $\operatorname{Max} 5004 x$ & 1.5 & $178 \mathrm{ab}$ & $14 \mathrm{bcd}$ & $95 \mathrm{bcd}$ & $37 \mathrm{abc}$ \\
\hline & $\operatorname{Max} 5005 x$ & 1.5 & $172 \mathrm{~b}$ & $16 \mathrm{bc}$ & $95 \mathrm{bcd}$ & $38 \mathrm{abc}$ \\
\hline & $\operatorname{Max} 10003 \times$ & 1.5 & $175 a b$ & $12 \mathrm{de}$ & $80 \mathrm{f}$ & $43 \mathrm{ab}$ \\
\hline & $\operatorname{Max} 10004 \times$ & 1.5 & $178 \mathrm{ab}$ & $17 \mathrm{ab}$ & $90 \mathrm{cdef}$ & $38 \mathrm{abc}$ \\
\hline & $\operatorname{Max} 10005 \times$ & 1.5 & $171 \mathrm{~b}$ & $20 \mathrm{a}$ & $91 \mathrm{cde}$ & $34 \mathrm{bc}$ \\
\hline & Prom500 $4 \times$ & 1.6 & $185 \mathrm{a}$ & $13 \mathrm{~cd}$ & $103 \mathrm{~b}$ & $36 \mathrm{bc}$ \\
\hline & Prom500 5x & 1.5 & $178 \mathrm{ab}$ & $17 \mathrm{abc}$ & $102 \mathrm{~b}$ & 35 bc \\
\hline & Tib100 1× & 1.6 & $183 \mathrm{a}$ & 9 ef & 84 ef & $42 \mathrm{abc}$ \\
\hline & Untreated & 1.5 & $180 \mathrm{ab}$ & $5 \mathrm{~g}$ & 119 a & $33 \mathrm{c}$ \\
\hline & $P$ & NS & $<0.0001$ & $<0.0001$ & $<0.0001$ & $<0.0001$ \\
\hline \multirow[t]{10}{*}{ Gala } & $\operatorname{Max} 5002 x$ & 1.4 & $183 \mathrm{bcd}$ & $15 a b c$ & $85 \mathrm{a}$ & 34 bcdef \\
\hline & $\operatorname{Max} 5003 \times$ & 1.6 & $187 \mathrm{abcd}$ & $15 \mathrm{abc}$ & $81 \mathrm{ab}$ & 34 abcde \\
\hline & $\operatorname{Max} 10005 \times$ & 1.5 & $181 \mathrm{~cd}$ & $16 \mathrm{ab}$ & $80 \mathrm{ab}$ & 31 bcdef \\
\hline & Prom500 $2 \times$ & 1.5 & 194 a & $13 \mathrm{bc}$ & $80 \mathrm{ab}$ & 35 abcd \\
\hline & Prom500 $3 \times$ & 1.5 & $195 \mathrm{a}$ & $12 \mathrm{c}$ & $77 \mathrm{~b}$ & 35 abcd \\
\hline & Prom500 4x & 1.5 & $190 \mathrm{abc}$ & $14 \mathrm{abc}$ & $85 \mathrm{a}$ & $40 \mathrm{a}$ \\
\hline & Prom500 5x & 1.6 & $192 \mathrm{ab}$ & $13 \mathrm{abc}$ & $84 \mathrm{a}$ & $36 a b c$ \\
\hline & Tib100 1× & 1.5 & $183 \mathrm{bcd}$ & $15 \mathrm{abc}$ & $83 \mathrm{a}$ & $36 \mathrm{ab}$ \\
\hline & Untreated & 1.5 & 196 a & $14 \mathrm{abc}$ & $81 \mathrm{ab}$ & 33 bcdef \\
\hline & $P$ & NS & $<0.0001$ & $<0.0001$ & $<0.0001$ & $<0.0001$ \\
\hline
\end{tabular}

Means within a column followed by different letters denote significant differences among treatments (Tukey's honestly significant difference, $P \leq 0.05$ ). TCSA $=$ trunk cross sectional area; $\mathrm{NS}=$ nonsignificant at $P \leq 0.05$.
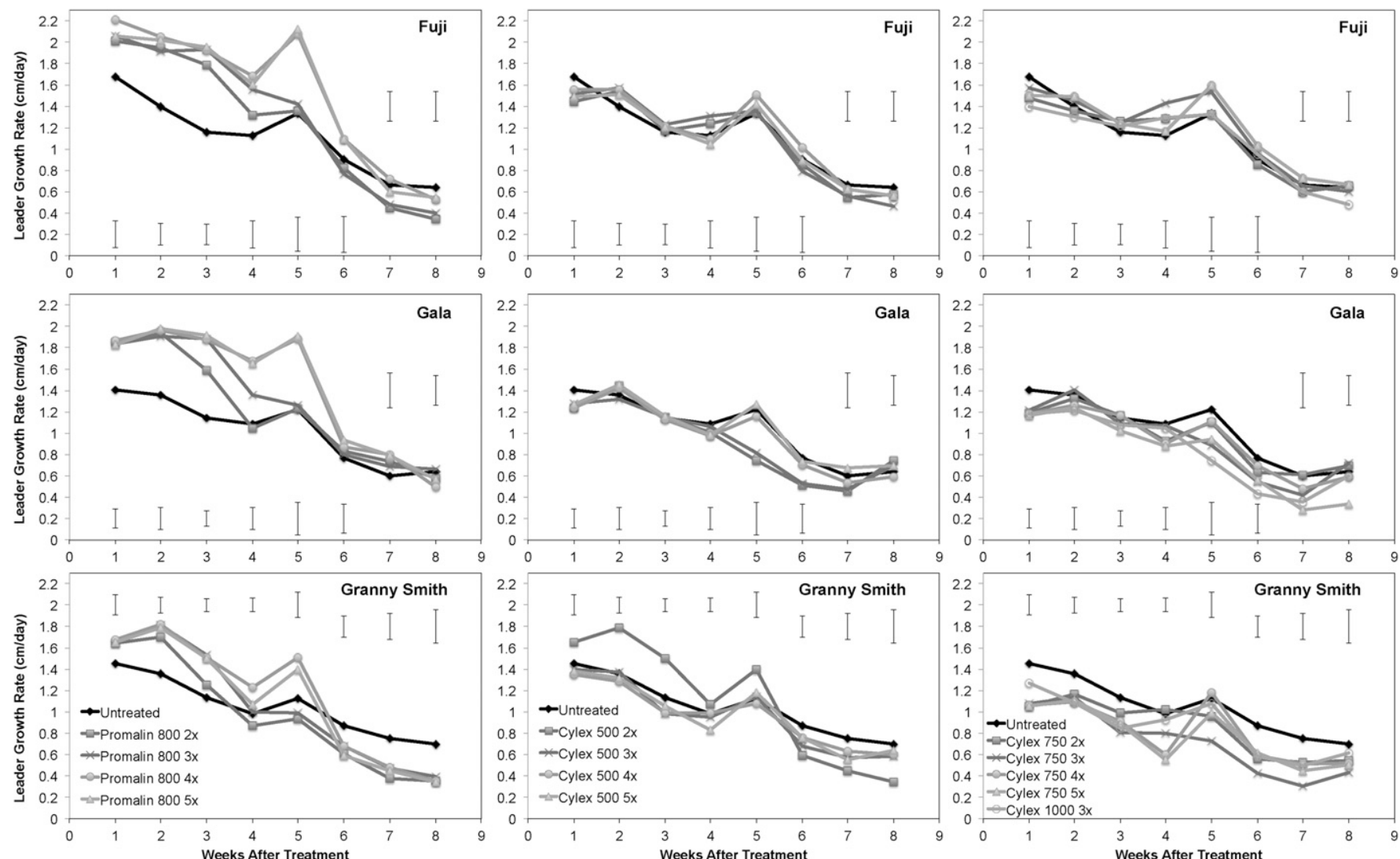

Fig. 2. Effects of plant growth regulator treatments at $500,750,800$, or $1000 \mathrm{mg} \cdot \mathrm{L}^{-1}$ sprayed from two to five times $(2 \times$ to $5 \times$ ) on leader growth rate $(\mathrm{cm}$ per day) on 'Fuji', 'Gala', and 'Granny Smith' in the nursery at Chile in 2012 (Experiment 4). All the treatments included Regulaid ${ }^{\circledR}$ at $0.125 \%(\mathrm{v} / \mathrm{v})$ as a surfactant. Vertical bars indicate least significant difference (LSD) at $P<0.05$. 
$\mathrm{MaxCel}^{\circledR}$ or Promalin ${ }^{\circledR}$ at $500 \mathrm{mg} \cdot \mathrm{L}^{-1}$. $\mathrm{MaxCel}^{\circledR}$ at higher rates $\left(1000 \mathrm{mg} \cdot \mathrm{L}^{-1}\right)$ and Tiberon $^{\mathrm{TM}}$ SC had the highest phytotoxicity values. Tiberon $^{\text {TM }}$ SC did not increase lateral shoot number, whereas increased number of shoots were observed when spraying either $\mathrm{MaxCel}^{\circledR}$ five times at $500 \mathrm{mg} \cdot \mathrm{L}^{-1}$ or four times at $1000 \mathrm{mg} \cdot \mathrm{L}^{-1}$. Average shoot height from the ground was higher on trees sprayed four to five times with either
$\mathrm{MaxCel}^{\circledR}$ or Promalin ${ }^{\circledR}$. Narrowest branch angles were observed on untreated and Tiberon $^{\top \mathrm{M}}$ SC sprayed-trees, whereas higher rates of $\mathrm{MaxCel}^{\circledR}\left(1000 \mathrm{mg} \cdot \mathrm{L}^{-1}\right)$ induced wider shoot angles. Shoots were longer on control and Tiberon ${ }^{\mathrm{TM}} \mathrm{SC}$ sprayed-trees.

Experiment 6: Cyclanilide, $B A$, and $B A$ plus $G A_{4+7}$ on 'Fuji' in 2013 in DE. TCSA was unaffected when applying $\mathrm{MaxCel}^{\circledR}$ and Promalin $^{\circledR}$ (at $\leq 500 \mathrm{mg} \cdot \mathrm{L}^{-1}$ ), or Tiberon ${ }^{\mathrm{TM}}$
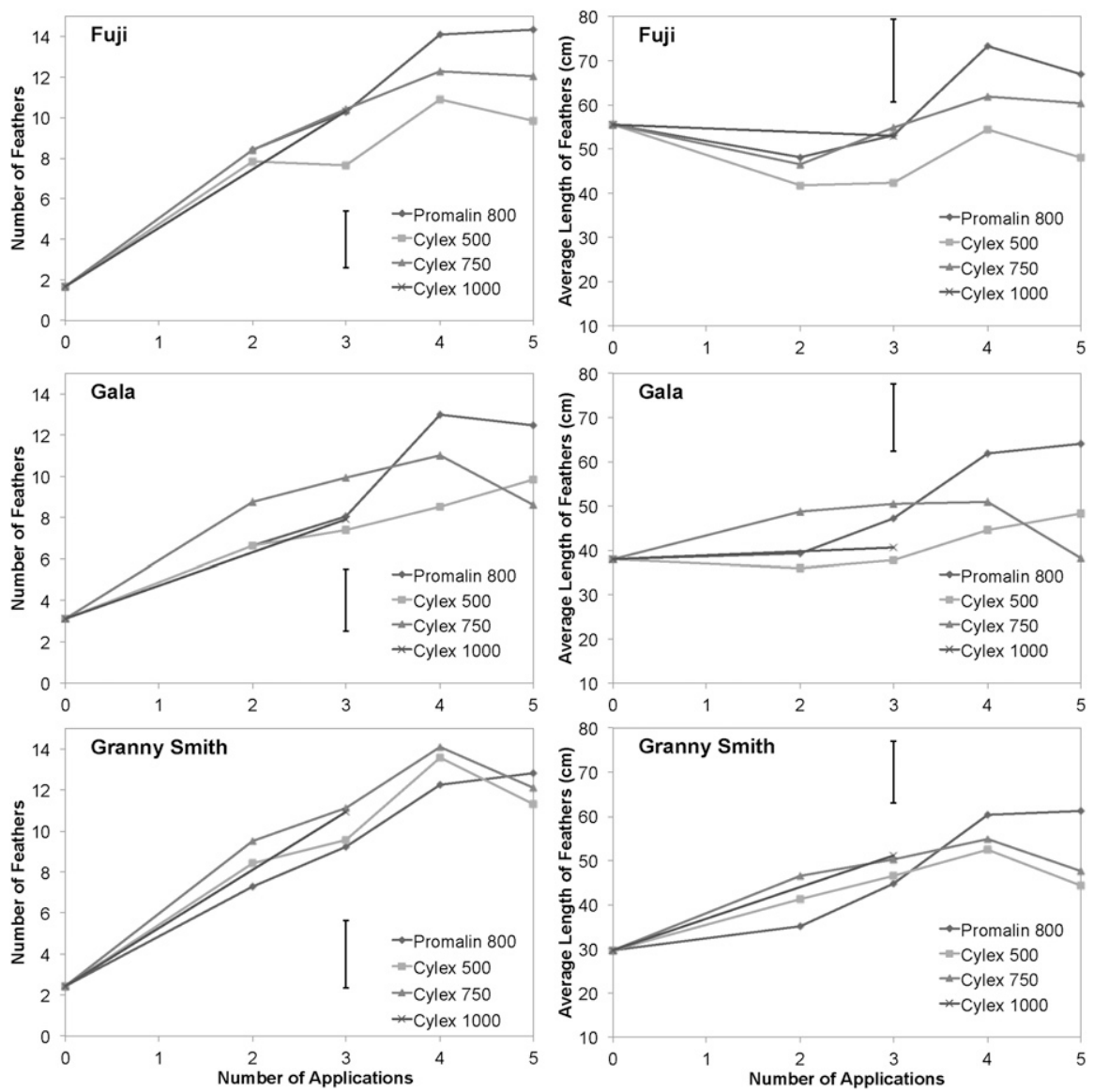

Fig. 3. Effects of plant growth regulator treatments at $500,750,800$, or $1000 \mathrm{mg} \cdot \mathrm{L}^{-1}$ on number and length of feathers on 'Fuji', 'Gala', and 'Granny Smith' in the nursery at Chile in 2012 (Experiment 4). All the treatments included Regulaid ${ }^{\circledR}$ at $0.125 \%(\mathrm{v} / \mathrm{v})$ as a surfactant. Vertical bars indicate least significant difference (LSD) at $P<0.05$.
$\mathrm{SC}$ (at $50 \mathrm{mg} \cdot \mathrm{L}^{-1}$ ) on 'Fuji' trees (Table 6). For the same dose, taller trees were observed when spraying Promalin ${ }^{\circledR}$ compared with $\mathrm{MaxCel}^{\circledR}$; however, no significant differences were observed when $\mathrm{MaxCel}^{\circledR}$ was reduced below $500 \mathrm{mg} \cdot \mathrm{L}^{-1}$. Higher number of shoots was observed when applying $\mathrm{MaxCel}^{\circledR}$ at $400-500 \mathrm{mg} \cdot \mathrm{L}^{-1}$ four times, or at $300 \mathrm{mg} \cdot \mathrm{L}^{-1}$ plus a surfactant. All the treatments significantly increased the number of shoots compared with the control, and the average shoot height was also increased when three or more sprays were done. However, crotch angle was only reduced when applying $\mathrm{MaxCel}^{\circledR}$ four times at $300-400 \mathrm{mg} \cdot \mathrm{L}^{-1}$ and a surfactant. This $\mathrm{MaxCel}^{\circledR}$ treatment also induced the shortest lateral shoots of any treatment.

Experiment 7: $B A$ and $B A$ plus $\mathrm{GA}_{4+7}$ on 'Macoun' in 2013 in DE. Promalin ${ }^{\circledR}$ at 400 $\mathrm{mg} \cdot \mathrm{L}^{-1}$ and $\mathrm{MaxCel}^{\circledR}$ at $300 \mathrm{mg} \cdot \mathrm{L}^{-1}$, both with a surfactant were the only two treatments that significantly increased tree height, whereas no differences were observed regarding TCSA among treatments (Table 7). On average, control trees of 'Macoun' had no lateral shoots at all, whereas all the PGR treatments increased lateral shoot number significantly. Higher number of shoots was observed when spraying $\mathrm{MaxCel}^{\circledR}$ at 400 $500 \mathrm{mg} \cdot \mathrm{L}^{-1}$, or Promalin ${ }^{\circledR}$ at $400 \mathrm{mg} \cdot \mathrm{L}^{-1}$ plus a surfactant. Average shoot height of the leader was increased with $\mathrm{MaxCel}^{\circledR}$ at 300 $\mathrm{mg} \cdot \mathrm{L}^{-1}$, and Promalin ${ }^{\circledR}$ at $400 \mathrm{mg} \cdot \mathrm{L}^{-1}$ plus a surfactant. Untreated trees had the narrowest lateral branch angles, followed by the ones sprayed with Promalin ${ }^{\circledR}$, and then those sprayed $\mathrm{MaxCel}^{\circledR}$ which had the widest angles. All the different treatments had considerably shorter lateral shoots compared with the control.

Experiment 8: Cyclanilide, BA, and BA plus $\mathrm{GA}_{4+7}$ on 'Fuji' and 'Gala' in 2013 in $W A$. No significant differences among treatments were observed in TCSA of 'Fuji' (Table 8). Tree height was reduced by $\mathrm{MaxCel}^{\circledR}$ when sprayed more than two times, but not by Promalin ${ }^{\circledR}$. As the number of sprays of $\mathrm{MaxCel}^{\circledR}{ }^{\circledR}$ increased greater negative effect on tree height. The untreated control trees had only one feather per tree, whereas trees treated

Table 5. Effects of various plant growth regulator treatments treated one to five times $(1 \times$ to $5 \times)$ at $50,100,500$, or $1000 \mathrm{mg} \cdot \mathrm{L}^{-1}$ on 'Golden Delicious' apple trees in Ellendale, DE, in 2012 (Experiment 5). All the treatments included Regulaid ${ }^{\circledR}$ at $0.125 \%(\mathrm{v} / \mathrm{v})$ as a surfactant. Shoot height from ground is the distance from the ground level to each of the induced feathers.

\begin{tabular}{|c|c|c|c|c|c|c|c|}
\hline Treatment & $\operatorname{TCSA}\left(\mathrm{cm}^{2}\right)$ & $\mathrm{Ht}(\mathrm{cm})$ & $\begin{array}{c}\text { Phytotoxicity } \\
(1=\text { none }, 10=\text { severe })\end{array}$ & Shoot number & $\begin{array}{l}\text { Shoot ht } \\
\text { from ground }(\mathrm{cm})\end{array}$ & $\begin{array}{l}\text { Shoot angle } \\
\text { (degrees) }\end{array}$ & $\begin{array}{c}\text { Shoot } \\
\text { length }(\mathrm{cm})\end{array}$ \\
\hline MaxCel1000 4x & $1.8 \mathrm{a}$ & $69 \mathrm{def}$ & $3.1 \mathrm{a}$ & $10 \mathrm{ab}$ & $39 a b c$ & $42 \mathrm{de}$ & $13 \mathrm{f}$ \\
\hline MaxCel1000 5x & $2.1 \mathrm{a}$ & $68 \mathrm{def}$ & $3.0 \mathrm{a}$ & $9 \mathrm{~b}$ & $38 \mathrm{bc}$ & $40 \mathrm{e}$ & 15 ef \\
\hline MaxCel500 4x & $2.2 \mathrm{a}$ & $73 a b c$ & $1.0 \mathrm{de}$ & $9 \mathrm{~b}$ & $40 \mathrm{ab}$ & $47 \mathrm{c}$ & $14 \mathrm{f}$ \\
\hline MaxCel500 5x & $2.1 \mathrm{a}$ & $74 \mathrm{ab}$ & $1.3 \mathrm{~cd}$ & $11 \mathrm{a}$ & $41 \mathrm{a}$ & $49 \mathrm{bc}$ & $13 \mathrm{f}$ \\
\hline Promalin500 $2 \times$ & $2.0 \mathrm{a}$ & $72 a b c$ & $0.3 \mathrm{f}$ & $7 \mathrm{~cd}$ & $36 \mathrm{~cd}$ & $50 \mathrm{bc}$ & $18 \mathrm{~cd}$ \\
\hline Tiberon50 2x & $1.9 \mathrm{a}$ & $66 \mathrm{f}$ & $1.4 \mathrm{~cd}$ & $5 \mathrm{de}$ & $37 \mathrm{c}$ & $53 \mathrm{ab}$ & $18 \mathrm{bc}$ \\
\hline Untreated & $2.2 \mathrm{a}$ & $71 \mathrm{bcd}$ & $0.0 \mathrm{f}$ & $5 \mathrm{e}$ & $34 \mathrm{~d}$ & $56 \mathrm{a}$ & $22 \mathrm{a}$ \\
\hline$P$ & 0.0061 & $<0.0001$ & $<0.0001$ & $<0.0001$ & $<0.0001$ & $<0.0001$ & $<0.0001$ \\
\hline
\end{tabular}

Means within a column followed by different letters denote significant differences among treatments (Tukey's honestly significant difference, $P \leq 0.05$ ). TCSA $=$ trunk cross sectional area. 
Table 6. Effects of various plant growth regulator treatments sprayed two to four times ( $2 \times$ to $4 \times)$ at $50,300,400$, or 500 mg. $\mathrm{L}^{-1}$ on 'Fuji' apple trees in Ellendale, DE, in 2013 (Experiment 6). Treatments with four sprays of $\mathrm{MaxCel}^{\circledR}$ at 300, 400 and $500 \mathrm{mg} \cdot \mathrm{L}^{-1}$ were sprayed with and without Regulaid ${ }^{\circledR}$ (Reg) at $0.125 \%$ $(\mathrm{v} / \mathrm{v})$ as a surfactant. Shoot height from ground is the distance from the ground level to each of the induced feathers.

\begin{tabular}{|c|c|c|c|c|c|c|}
\hline Treatment & $\operatorname{TCSA}\left(\mathrm{cm}^{2}\right)$ & $\mathrm{Ht}(\mathrm{cm})$ & Shoot number & Shoot ht from ground $(\mathrm{cm})$ & Shoot angle (degrees) & Shoot length $(\mathrm{cm})$ \\
\hline$\overline{\mathrm{MaxCel} 3004 \times}$ & 1.7 & $173 \mathrm{abc}$ & $11 \mathrm{de}$ & $104 \mathrm{ab}$ & 67 abcde & $28 \mathrm{~cd}$ \\
\hline MaxCel300 + Reg $4 \times$ & 1.9 & $177 \mathrm{ab}$ & $16 \mathrm{abc}$ & $108 \mathrm{a}$ & $62 \mathrm{e}$ & $25 \mathrm{~d}$ \\
\hline MaxCel400 3x & 1.7 & $170 \mathrm{abc}$ & $15 \mathrm{bc}$ & $97 \mathrm{bc}$ & $69 \mathrm{abc}$ & $29 \mathrm{~cd}$ \\
\hline MaxCel400 4x & 1.7 & $172 \mathrm{abc}$ & $16 \mathrm{abc}$ & $100 \mathrm{bc}$ & $70 \mathrm{ab}$ & $30 \mathrm{~cd}$ \\
\hline MaxCel400 + Reg 4x & 1.8 & $176 \mathrm{ab}$ & $19 \mathrm{a}$ & $105 \mathrm{ab}$ & 62 de & $24 \mathrm{~d}$ \\
\hline MaxCel500 2x & 1.6 & $167 \mathrm{bc}$ & $13 \mathrm{~cd}$ & $87 \mathrm{de}$ & 67 abcde & $32 \mathrm{c}$ \\
\hline MaxCel500 3x & 1.7 & $165 \mathrm{c}$ & $15 \mathrm{bcd}$ & $95 \mathrm{~cd}$ & 67 abcd & $30 \mathrm{~cd}$ \\
\hline MaxCe1500 4x & 1.6 & $170 \mathrm{abc}$ & $17 \mathrm{ab}$ & $99 \mathrm{bc}$ & 66 bcde & $29 \mathrm{~cd}$ \\
\hline MaxCel500 + Reg $4 \times$ & 1.7 & $169 \mathrm{bc}$ & $19 \mathrm{a}$ & $99 \mathrm{bc}$ & $65 \mathrm{cde}$ & $26 \mathrm{~cd}$ \\
\hline Promalin500 $4 \times$ & 1.7 & $180 \mathrm{a}$ & $14 \mathrm{bcd}$ & $100 \mathrm{abc}$ & 66 abcde & $27 \mathrm{~cd}$ \\
\hline Tiberon50 $2 \times$ & 1.7 & $171 \mathrm{abc}$ & 8 e & $86 \mathrm{e}$ & $71 \mathrm{a}$ & $44 \mathrm{~b}$ \\
\hline Untreated & 1.7 & $171 \mathrm{abc}$ & $3 \mathrm{f}$ & 82 e & $68 \mathrm{abc}$ & $51 \mathrm{a}$ \\
\hline$P$ & NS & 0.0002 & $<0.0001$ & $<0.0001$ & $<0.0001$ & $<0.0001$ \\
\hline
\end{tabular}

Means within a column followed by different letters denote significant differences among treatments (Tukey's honestly significant difference, $P \leq 0.05)$. TCSA $=$ trunk cross sectional area; NS = nonsignificant at $P \leq 0.05$.

Table 7. Effects of various plant growth regulator treatments sprayed four times (4×) at 300, 400, or 500 mg. $\mathrm{L}^{-1}$ on 'Macoun' apple trees in Ellendale, DE, in 2013 (Experiment 7). Rates of 300 and $400 \mathrm{mg} \cdot \mathrm{L}^{-1}$ were applied with and without the surfactant Regulaid ${ }^{\circledR}$ (Reg) at $0.125 \%$ (v/v). Shoot height from ground is the distance from the ground level to each of the induced feathers.

\begin{tabular}{|c|c|c|c|c|c|c|}
\hline Treatment & $\operatorname{TCSA}\left(\mathrm{cm}^{2}\right)$ & $\mathrm{Ht}(\mathrm{cm})$ & Shoot number & Shoot ht from ground $(\mathrm{cm})$ & Shoot angle (degrees) & Shoot length $(\mathrm{cm})$ \\
\hline MaxCel300 4× & 1.8 & $157 \mathrm{bc}$ & $5 \mathrm{c}$ & $96 \mathrm{a}$ & $50 \mathrm{bc}$ & $19 \mathrm{~b}$ \\
\hline MaxCel300 + Reg $4 \times$ & 1.8 & $161 \mathrm{ab}$ & $10 \mathrm{~b}$ & $89 \mathrm{ab}$ & $50 \mathrm{bc}$ & $18 \mathrm{~b}$ \\
\hline MaxCel400 4x & 1.9 & $156 \mathrm{bc}$ & $12 \mathrm{ab}$ & $88 \mathrm{bc}$ & $48 \mathrm{c}$ & $20 \mathrm{~b}$ \\
\hline MaxCel400 + Reg $4 \times$ & 1.7 & $156 \mathrm{bc}$ & $10 \mathrm{~b}$ & $88 \mathrm{bc}$ & $48 \mathrm{c}$ & $20 \mathrm{~b}$ \\
\hline MaxCel500 4× & 1.7 & $153 \mathrm{bc}$ & $13 \mathrm{a}$ & $85 \mathrm{bc}$ & $43 \mathrm{~d}$ & $19 \mathrm{~b}$ \\
\hline Promalin400 $4 \times$ & 1.8 & $155 \mathrm{bc}$ & $6 \mathrm{c}$ & $86 \mathrm{bc}$ & $53 \mathrm{~b}$ & $22 \mathrm{~b}$ \\
\hline Promalin $400+\operatorname{Reg} 4 \times$ & 1.9 & $171 \mathrm{a}$ & $11 \mathrm{ab}$ & $96 \mathrm{a}$ & $51 \mathrm{~b}$ & $20 \mathrm{~b}$ \\
\hline Promalin500 $4 \times$ & 1.8 & $159 \mathrm{bc}$ & $6 \mathrm{c}$ & $81 \mathrm{c}$ & $53 \mathrm{~b}$ & $25 \mathrm{~b}$ \\
\hline Untreated & 1.7 & $150 \mathrm{c}$ & $0 \mathrm{~d}$ & $78 \mathrm{bc}$ & $59 a$ & $46 \mathrm{a}$ \\
\hline$P$ & NS & $<0.0001$ & $<0.0001$ & $<0.0001$ & $<0.0001$ & $<0.0001$ \\
\hline
\end{tabular}

Means within a column followed by different letters denote significant differences among treatments (Tukey's honestly significant difference, $P \leq 0.05)$. TCSA $=$ trunk cross sectional area; NS = nonsignificant at $P \leq 0.05$.

with either $\mathrm{MaxCel}^{\circledR}$, Promalin $^{\circledR}$, or Tiberon ${ }^{\mathrm{TM}}$ $\mathrm{SC}$ had from two to six feathers. Increasing the rate of $\mathrm{MaxCel}^{\circledR}$ from 500 to $750 \mathrm{mg} \cdot \mathrm{L}^{-1}$ did not induce significantly more feathers. Promalin ${ }^{\circledR}$ was only tested with four applications, and no significant differences were observed regarding the number of shoots for the two tested rates $\left(500\right.$ and $\left.750 \mathrm{mg} \cdot \mathrm{L}^{-1}\right)$. A single spray of Tiberon ${ }^{\mathrm{TM}} \mathrm{SC}$ induced the same number of feathers as four sprays of MaxCel ${ }^{\circledR}$ or Promalin ${ }^{\circledR}$. The average length of feathers was decreased by sprays of MaxCel $^{\circledR}$, Promalin $^{\circledR}$, or Tiberon $^{\mathrm{TM}}$ SC. Shoot height was higher on untreated trees and when spraying four times with the higher rates of either MaxCel ${ }^{\circledR}$ or Proma$\operatorname{lin}^{\circledR}$. Tiberon ${ }^{\mathrm{TM}} \mathrm{SC}$ applications induced the narrowest branch angles compared with untreated control trees, or Promalin ${ }^{\circledR}$, or MaxCel ${ }^{\circledR}$ treated trees.

No differences between the control and the rest of treatments were observed in TCSA of 'Gala'. Tree height of 'Gala' was reduced by high rates of $\mathrm{MaxCel}^{\circledR}$, and as the number of sprays increased the negative effect on tree height was greater. No significant differences regarding shoot number were observed for 'Gala'. The average length of feathers was unaffected by MaxCel ${ }^{\circledR}$, Promalin ${ }^{\circledR}$, or Tiberon ${ }^{\mathrm{TM}}$ SC. Shoot height was higher than the untreated control when trees were sprayed one time with Tiberon ${ }^{\mathrm{TM}} \mathrm{SC}$ or with $\mathrm{MaxCel}^{\circledR}$ and Promalin ${ }^{\circledR}$ when sprayed more than two times.
Experiment 9: $B A$ and $B A$ plus $G A_{4+7}$ on 'Fuji' in 2014 in DE. Increasing the Promalin ${ }^{\circledR}$ dose from 400 to $500 \mathrm{mg} \cdot \mathrm{L}^{-1}$ slightly increased the TCSA of treated trees compared with the untreated control trees (Table 9). Similarly to previous experiments, Promalin ${ }^{\circledR}$ increased tree height compared with $\mathrm{MaxCel}^{\circledR}$ sprays. Higher quality ratings were observed when using the highest doses $\left(500 \mathrm{mg} \cdot \mathrm{L}^{-1}\right)$ and number of sprays (Five sprays) for both $\mathrm{MaxCel}^{\circledR}$ and Promalin ${ }^{\circledR}$, whereas phytotoxicity was almost nonexistent across all the treatments. Higher doses and number of sprays also induced more lateral shoots, and similar numbers were observed when applying either $\mathrm{MaxCel}^{\circledR}$ four times at 500 $\mathrm{mg} \cdot \mathrm{L}^{-1}$, or five times at $400 \mathrm{mg} \cdot \mathrm{L}^{-1}$. Similar responses were observed regarding Proma$\operatorname{lin}^{\circledR}$ and the average shoot height. MaxCel ${ }^{\circledR}$ induced wider shoot angles compared with Promalin ${ }^{\circledR}$, with more upright shoots observed on the control trees. No significant differences were observed regarding shoot length when comparing $\mathrm{MaxCel}^{\circledR}$ vs. Promalin ${ }^{\circledR}$ sprays. Longer shoots were observed on untreated trees.

Experiment 10: $B A$ and $B A$ plus $G A_{4+7}$ on a Range of Varieties in 2014-15 in DE. In 2014, 'Cripps Pink', 'Enterprise', and 'Fuji' had the highest tree quality ratings when sprayed with either Promalin ${ }^{\circledR}$ or MaxCel $^{\circledR}$ (Fig. 4). 'Ambrosia', 'Crimson Crisp', and 'Gala' had the next highest quality ratings, whereas 'Cortland', 'Aceymac', 'Goldrush',
'Honeycrisp', and 'Suncrisp' had the least branching response to Promalin ${ }^{\circledR}$ or $\mathrm{MaxCe}^{\circledR}$.

In 2015, 'Aceymac', 'Enterprise', and 'Gingergold' had the highest tree quality ratings when sprayed with either Promalin ${ }^{\circledR}$ or $\mathrm{MaxCel}^{\circledR}$. 'Cameo', 'Crimson Crisp', 'Fuji', 'Gala', and 'Granny Smith' had lower quality ratings, followed by 'Cripps Pink', 'Suncrisp', and 'Macoun'. 'Ambrosia', 'Cortland', 'Goldrush', and 'Honeycrisp' had the lowest ratings.

For both years, there were no significant differences in tree quality between those treated with Promalin ${ }^{\circledR}$ or MaxCel ${ }^{\circledR}$ when averaged over all the varieties (data not shown).

Experiment 11: Inhibition of flowering in 2013 in NY, UT, and NC. Application of gibberellins in the late summer during the nursery year reduced flowering in both 'Gala' and 'Pink Lady' the following year in the orchard (Table 10). Untreated 'Gala' trees produced about five flower clusters per tree, whereas 'Pink Lady' produced about 18 flower clusters/tree. The low rate of $\mathrm{GA}_{3}$ (100 mg. $\mathrm{L}^{-1}$ ) reduced flowering of the 'Gala' trees planted at NY, but not the 'Gala' trees planted at Utah. The highest rates of $\mathrm{GA}_{3}$ or $\mathrm{GA}_{4+7}$ were the most effective treatments and essentially eliminated flowering in 'Gala'. With 'Pink Lady', the highest rate of $\mathrm{GA}_{3}$ was better than the lowest, but did not totally eliminate flowering. Increasing the number of sprays also resulted in reduced flowering 
Table 8. Effects of MaxCel ${ }^{\circledR}$ (Max), Promalin ${ }^{\circledR}$ (Prom), or Tiberon ${ }^{\text {TM }}$ SC (Tib) sprayed one to four times (1× to $4 \times$ ) at 100,500 , or $750 \mathrm{mg} \cdot \mathrm{L}^{-1}$ on 'Fuji' and 'Gala' apple trees in the nursery at Washington State in 2013 (Experiment 8). All the treatments included Regulaid ${ }^{\circledR}$ at $0.125 \%$ (v/v) as a surfactant. Shoot height from ground is the distance from the ground level to each of the induced feathers.

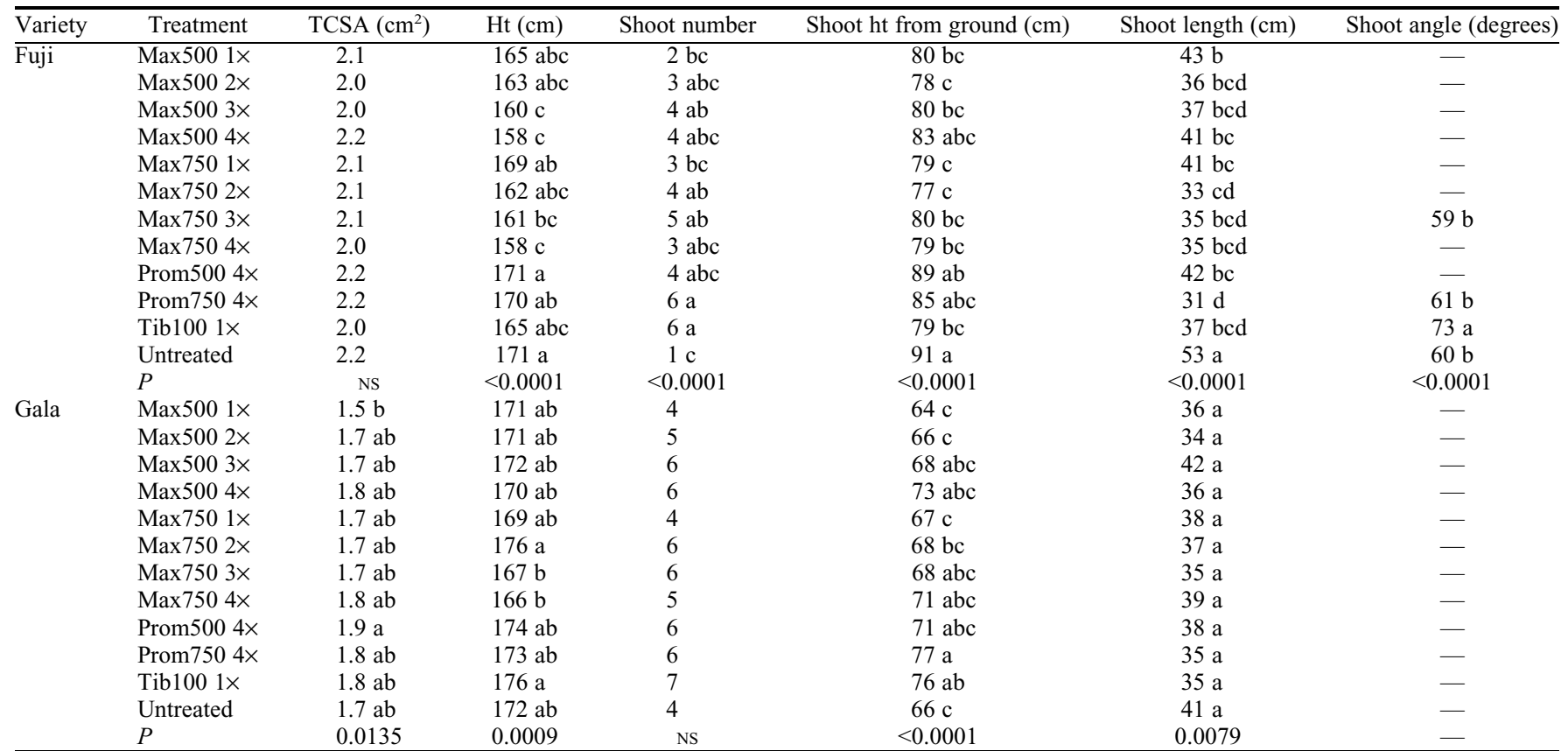

Means within a column followed by different letters denote significant differences among treatments (Tukey's honestly significant difference, $P \leq 0.05$ ). TCSA $=$ trunk cross sectional area; Ns $=$ nonsignifigant at $P \leq 0.05$.

Table 9. Effects of various plant growth regulator treatments treated either four or five times $(4 \times, 5 \times)$ at 400 or $500 \mathrm{mg} \cdot \mathrm{L}^{-1}$ on 'Fuji' apple trees in Ellendale, DE, in 2014 (Experiment 9). All the Promalin ${ }^{\circledR}$ applications included Regulaid ${ }^{\circledR}$ at $0.125 \%$ (v/v) as a surfactant. Shoot height from ground is the distance from the ground level to each of the induced feathers.

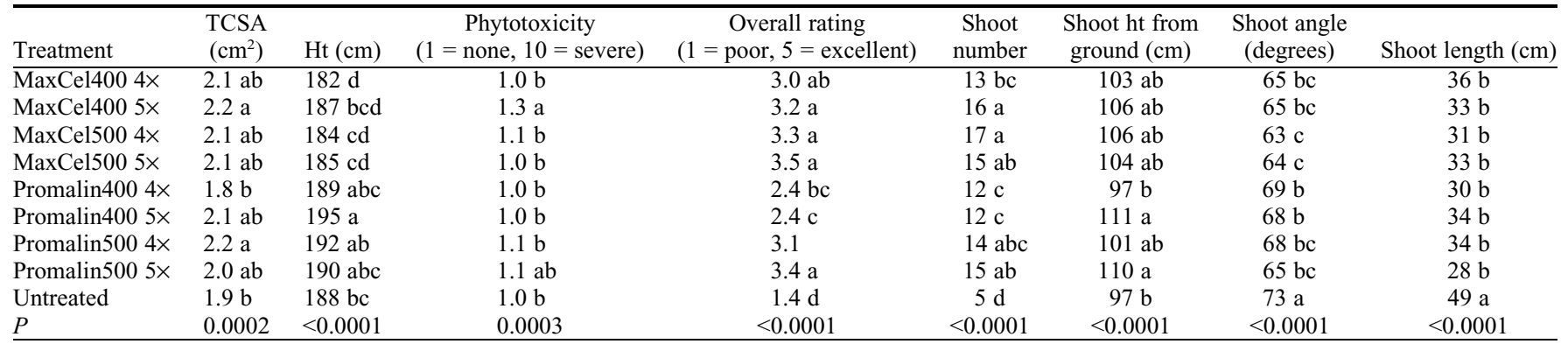

Means within a column followed by different letters denote significant differences among treatments (Tukey's honestly significant difference, $P \leq 0.05$ ). TCSA $=$ trunk cross sectional area.

the next year. Four sprays of $\mathrm{GA}_{4+7}$ at $250 \mathrm{mg} \cdot \mathrm{L}^{-1}$ was the best treatment for both varieties.

\section{Discussion}

Cyclanilide, $\mathrm{BA}$, and $\mathrm{BA}+\mathrm{GA}_{4+7}$ were effective in inducing branching on several varieties in our experiments. Branching increase by $\mathrm{BA}+\mathrm{GA}_{4+7}$ has been reported on 'Jonica' and 'Sampion' apple varieties by Kapłan (2010); and on 'Liberty' x 'Starking Delicious', and 'Liberty' $x$ 'Macspur' hybrids by Jacyna and Barnard (2008). On the other hand, other authors (Hrotko et al., 2000) found increased feathering on 'Idared' and 'Egri piros' by spraying BA. Among the three PGRs tested here, cyclanilide induced the least amount of branching, and it also reduced final caliper and tree height, resulting in poor tree architecture. This effect was dose dependent and the negative effects on tree growth were more evident on 'Macoun', 'Gala', 'Granny Smith', and 'Golden Delicious', than on 'Fuji'. Negative effects were also observed on 'Macoun', 'Fuji', 'Aceymac', and 'Empire' in a previous experiment in NY (Miranda Sazo and Robinson, 2011). Conversely, Elfving and Visser (2005) did not observe leader growth differences either on 'Fuji', 'Cameo', or 'Scarletspur Delicious' when spraying cyclanilide in Washington State. Most likely, this was due to greater shoot growth rate in Washington State than under Eastern US climatic conditions. An influence of temperature on branching response has been reported by the nurserymen in Italy, where they observe better results when BA sprays are followed by a $3 \mathrm{~h}$ period of at least $18{ }^{\circ} \mathrm{C}\left(65^{\circ} \mathrm{F}\right)$ (Leo Forcher, personal communication). In our study 'Gala' was tested in WA, DE, and
Chile. Although no more feathers were observed in WA when spraying either Max$\mathrm{Cel}^{\circledR}$ or Promalin ${ }^{\circledR}$, higher quality trees were observed when spraying both products in $\mathrm{DE}$, whereas in Chile only Promalin ${ }^{\circledR}$ gave more feathers on 'Gala'. Higher temperatures and lower RH were observed in Quincy, WA, compared with Ellendale, DE, whereas in Santiago Chile (December) weather was in between DE and WA. The lowest RH and highest temperatures observed in WA may result in quicker drying of the PGR solution, hindering its uptake and activity. On the other hand, the highest RH observed in DE might have allowed longer drying time resulting in more uptake of the PGR, resulting in the better response we observed.

Both BA and Promalin ${ }^{\circledR}$ induced greater number of branches than cyclanilide in our studies and had smaller negative effect on final tree height. Tree height was reduced 

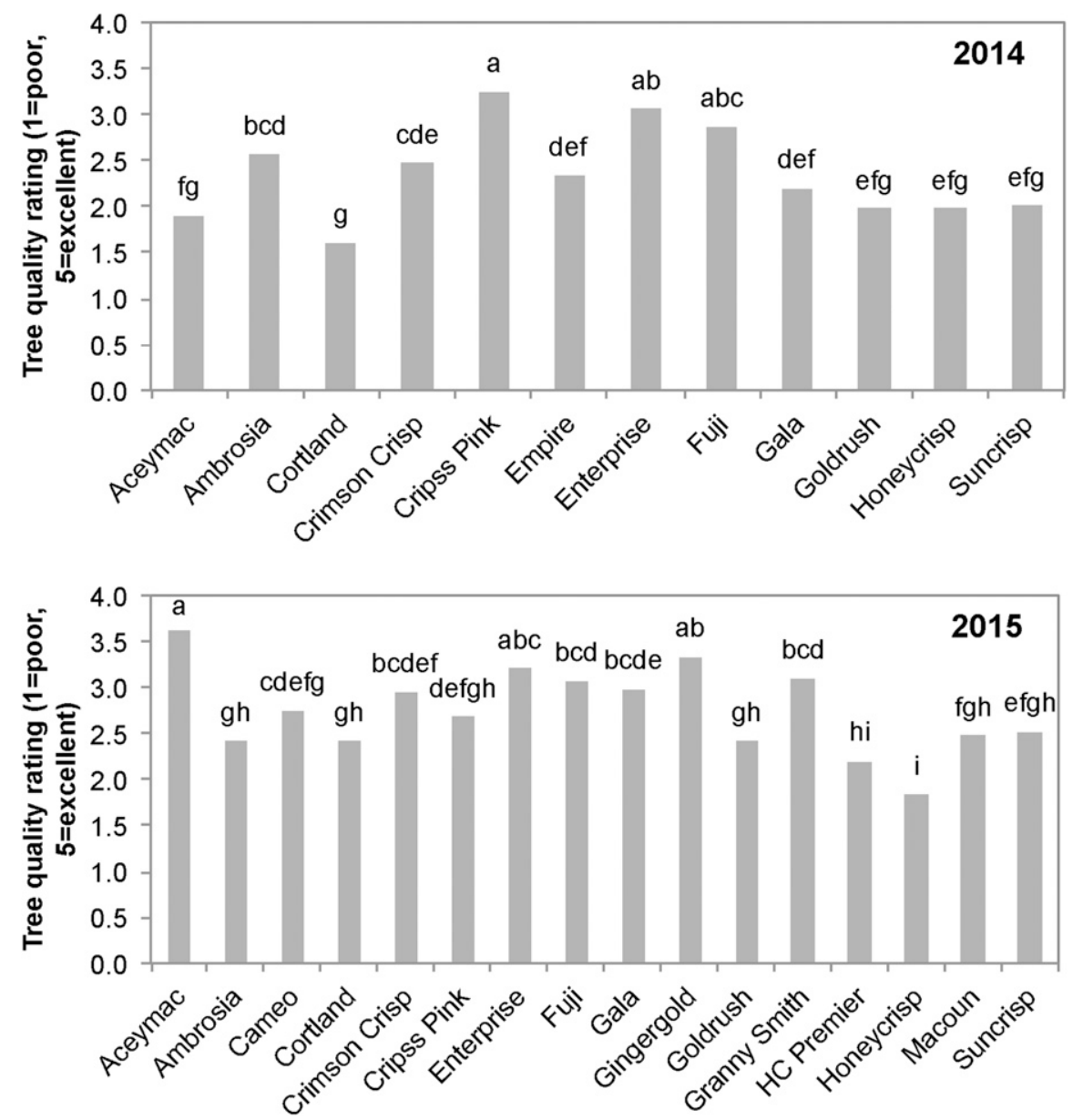

Fig. 4. Effects of four or five applications of either MaxCel ${ }^{\circledR}$ or Promalin ${ }^{\circledR}$ on the overall tree quality of 17 apple varieties in Ellendale, DE, in 2014 and 2015 (Experiment 10). Tree quality $(1=$ poor, $5=$ excellent) was subjectively assessed, taking into account overall tree height, number of feathers, and their angle. Excellent quality trees had a tree height of 180-200 cm and 12-15 wide-angle feathers, whereas poor quality trees were short in height and with no feathers at all. All the Promalin applications included Regulaid ${ }^{\circledast}$ at $0.125 \%(\mathrm{v} / \mathrm{v})$ as a surfactant. Bars with different letters denote significant differences among varieties (Tukey's honestly significant difference, $P \leq 0.05$ ).

Table 10. Effects of gibberellin treatment in the nursery on flowering of 'Gala' and 'Pink Lady' apple trees the next year in the orchard (Experiment 11).

\begin{tabular}{lccc}
\hline Treatment & Gala (NY) & Gala (UT) & Pink lady (NC) \\
\hline Untreated Control & $4.5 \mathrm{a}$ & $5.6 \mathrm{a}$ & $17.5 \mathrm{ab}$ \\
$100 \mathrm{mg} \cdot \mathrm{L}^{-1} \mathrm{GA}_{3} 2 \times$ & $1.2 \mathrm{bc}$ & $5.0 \mathrm{ab}$ & $17.0 \mathrm{abc}$ \\
$100 \mathrm{mg} \cdot \mathrm{L}^{-1} \mathrm{GA}_{3} 3 \times$ & $0.6 \mathrm{c}$ & $4.5 \mathrm{ab}$ & $17.7 \mathrm{a}$ \\
$100 \mathrm{mg} \cdot \mathrm{L}^{-1} \mathrm{GA}_{3} 4 \times$ & $0.5 \mathrm{c}$ & $7.3 \mathrm{a}$ & $14.2 \mathrm{~cd}$ \\
$250 \mathrm{mg} \cdot \mathrm{L}^{-1} \mathrm{GA}_{3} 2 \times$ & $2.2 \mathrm{~b}$ & $6.1 \mathrm{a}$ & $13.7 \mathrm{~d}$ \\
$250 \mathrm{mg} \cdot \mathrm{L}^{-1} \mathrm{GA}_{3} 3 \times$ & $2.3 \mathrm{~b}$ & $5.6 \mathrm{a}$ & $14.8 \mathrm{bcd}$ \\
$250 \mathrm{mg} \cdot \mathrm{L}^{-1} \mathrm{GA}_{3} 4 \times$ & $0.7 \mathrm{c}$ & $1.5 \mathrm{bc}$ & $11.9 \mathrm{~d}$ \\
$250 \mathrm{mg} \cdot \mathrm{L}^{-1} \mathrm{GA}_{4+7} 3 \times$ & $0.0 \mathrm{c}$ & $0.5 \mathrm{c}$ & $12.7 \mathrm{~d}$ \\
\hline
\end{tabular}

Means within a column followed by different letters denote significant differences among treatments (Tukey's honestly significant difference, $P \leq 0.05$ ).

when using MaxCel ${ }^{\circledR}$ compared with Promalin ${ }^{\circledR}$. Similar tree height decreases were reported by Palmer et al., (2011) when spraying the cytokinins, thidiazuron and benzyladenine, on pear trees. Similar to our results, Jacyna and Barnard (2008) observed greater leader growth on different apple hybrids when spraying Promalin ${ }^{\circledR}$ at $250-750 \mathrm{mg} \cdot \mathrm{L}^{-1}$.

Higher rates of BA were tested in our first experiments (1-5), but we did not see significant differences regarding lateral shoot number when comparing $500 \mathrm{mg} \cdot \mathrm{L}^{-1}$ vs. 1000 $\mathrm{mg} \cdot \mathrm{L}^{-1}$ on 'Macoun', 'Fuji', 'Gala', 'Granny Smith', and 'Golden Delicious'. Hence, lower rates and more sprays were assessed in subsequent experiments (6-10). Higher number of shoots was observed when using MaxCel ${ }^{\circledR}$ at $400-500 \mathrm{mg} \cdot \mathrm{L}^{-1}$, or $300 \mathrm{mg} \cdot \mathrm{L}^{-1}$ plus a surfactant. However, adding a surfactant to MaxCel ${ }^{\circledR}$ caused significant phytotoxicity in previous studies (Robinson et al., 2014). This may be explained because the $\mathrm{MaxCel}^{\circledR}$ formulation already contains proprietary surfactants (Gregory Clarke, personal communication). With the exception of the $1000 \mathrm{mg} \cdot \mathrm{L}^{-1}$ rate $(2 \times$ label $)$, we did not observe significant phytotoxicity when using Promalin ${ }^{\circledR}$; still, when using a surfactant Miller and Eldridge (1986) reported some phytotoxicity on 'Delicious' trees when applying it at $300-500 \mathrm{mg} \cdot \mathrm{L}^{-1}$ rates. However, Miller and Eldridge (1986) reported identical responses when a much lower surfactant rate was also used together with Promalin ${ }^{\circledR}$.

Compared with untreated trees, sprays of either BA or Promalin ${ }^{\circledR}$ increased the number of feathers by three-to-four times and reduced their crotch angle (flatter branches). Conversely, Keever et al. (1993) reported a crotch angle increase when spraying either BA or Promalin ${ }^{\circledR}$ on 'Bradford' pear trees. In our study, the widest shoots where observed when spraying $\mathrm{MaxCel}^{\circledR}$ compared with Promalin $^{\circledR}$. A study done by Elfving and Visser (2005) on 'Scarletspur Delicious' trees reported a branch angle increase (more upright) when cyclanilide plus Promalin ${ }^{\circledR}$ were sprayed together, compared with single sprays of cyclanilide.

Significant variety effects were observed in our study, for instance with 'Fuji' we induced an average of 16 branches compared with 14 for 'Gala', and 10 for 'Golden Delicious' or 'Macoun'. Overall, we observed good response and quality ratings on 'Cameo', 'Cripps Pink', 'Enterprise', 'Fuji', 'Ambrosia', 'Crimson Crisp', 'Gingergold', 'Gala', and 'Granny Smith' when spraying five times either Promalin ${ }^{\circledR}$ or $\mathrm{MaxCel}^{\circledR}$ at 400-500 $\mathrm{mg} \cdot \mathrm{L}^{-1}$. On the other hand, varieties such as 'Ambrosia', 'Cortland', 'Goldrush', 'Honeycrisp', and 'Suncrisp' had the lowest ratings. Because we know of no published branching studies for such varieties, it is difficult to contrast our observations. The less branching induced on 'Honeycrisp' could be explained because of its weak growing habit. On the other hand, even though 'Ambrosia', 'Cortland', 'Goldrush', and 'Suncrisp' have less vigor than 'Fuji', their poor response to branching sprays might be explained by a strong apical dominance. In addition, 'Suncrisp' was observed to be very rate dependent, being more responsive at lower rates and more subject to phytotoxicity (data not shown).

Four sprays of $\mathrm{GA}_{3}$ or three of $\mathrm{GA}_{4+7}$ at $250 \mathrm{mg} \cdot \mathrm{L}^{-1}$ essentially eliminated flowering in 'Gala', whereas it was not quite enough on 'Pink Lady'. Davis (2002) observed that $\mathrm{GA}_{4+7}$ more effectively suppressed flowering than $\mathrm{GA}_{3}$ on 'Ramey York' in Blacksburg, Virginia. However, we cannot support that because multiple rates and spray times for $\mathrm{GA}_{4+7}$ were not examined in our study. For the same treatments, there were far fewer flowers on 'Gala' in NY compared with UT. Trees were dug in Nov. 2013 and kept all together in cold storage during winter before planting them in spring at the different locations. Therefore, differences within locations must be explained by flower damage due to low spring temperatures, which were considerably lower in NY than in UT (Fig. 1). Flower induction in apple occurs in early summer (Ferree and Warrington, 2003), thus, 
because flower bud initiation occurred when trees from both locations were under the same conditions, lower temperatures could cause some damage to floral buds in NY, rather than being a different gibberellin response to temperature.

To enhance branching on nursery trees, the best results were obtained with four applications at 2-week intervals of either $\mathrm{MaxCel}^{\circledR}$ or Promalin $^{\circledR}$ at $400 \mathrm{mg} \cdot \mathrm{L}^{-1}$. Promalin ${ }^{\circledR}$ was slightly less effective branching agent than $\mathrm{MaxCel}^{\circledR}$, but its effect could be improved by adding Regulaid ${ }^{\circledR}$ as a surfactant at $0.125 \%(\mathrm{v} / \mathrm{v})$. On the other hand, Promalin $^{\circledR}$ stimulated leader growth rate resulting in improved final tree height, whereas MaxCel ${ }^{\circledR}$ induced the widest branch angles. Sprays could be increased up to five times on varieties less prone to branching such as 'Macoun' and 'Golden Delicious'.

\section{Literature Cited}

Basak, A., P. Kolodziejczak, and T. Buban. 1992. Paturyl $10 \mathrm{WSC}$ as a branching agent for young apple trees in nursery and orchards. Acta Hort. 329:201-203.

Cody, C., F. Larsen, and R. Fritts, Jr. 1985. Stimulation of lateral branch development in tree fruit nursery stock with $\mathrm{GA}_{4+7}+\mathrm{BA}$. HortScience 20:758-759.

Davis, D.E. 2002. Inhibition of flower bud initiation and development in apple by defoliation, gibberellic acid and crop load manipulation. Virginia Polytechnic Inst. State Univ., PhD Diss.

Elfving, D.C. and D.B. Visser. 2005. Cyclanilide induces lateral branching in apple trees. HortScience 40:119-122.

Elfving, D.C. and D.B. Visser. 2006a. Cyclanilide induces lateral branching in sweet cherry trees. HortScience 41:149-153.

Elfving, D.C. and D.B. Visser. 2006b. Timing cyclanilide and cytokinin applications in the nursery to obtain desired lateral branch height in apple and sweet cherry trees. HortScience 41:1238-1242.
Ferree, D.C. and I.J. Warrington. 2003. Apples: Botany, production and uses. CABI publishing, Cambridge, MA.

Forshey, C. 1982. Branching responses of young apple trees to applications of 6-benzylamino purine and gibberellin $\mathrm{A}_{4+7}$. J. Amer. Soc. Hort. Sci. 107:1092-1097.

Greene, D. and P. Miller. 1988. Effects of growth regulator sprays and notching on growth and branching of 'Starkrimson Delicious' apple trees. J. Amer. Soc. Hort. Sci. 113:18-23.

Greene, D.W. 2000. Reducing floral initiation and return bloom in pome fruit trees - applications and implications. Hort Technology 10:740 743.

Greene, D.W. and W.R. Autio. 1994. Notching techniques increase branching of young apple trees. J. Amer. Soc. Hort. Sci. 119:678-682.

Hrotko, K., L. Magyar, and Z. Ronay. 2000 Improved feathering on apple nursery trees by BA application. Acta Hort. 514:113-122.

Jacyna, T. and J. Barnard. 2008. Modification of branching behavior in apical-dominant apple trees with plant growth regulators and their residual effects on tree growth after transplanting. J. Amer. Pomol. Soc. 62(4):160-172.

Jaumien, F., B. Czarnecki, W. Poniedzialek, and T. Mitrut. 1993. Very similar effects of a mixture of $\mathrm{GA}_{3}$ and $\mathrm{BA}$ (6-benzylaminopurine) and of $\mathrm{GA}_{4+7}$ and BA on branching of some apple cultivars in nursery. Acta Hort. 329:35-42.

Jonkers, H. 1979. Biennial bearing in apple and pear: A literature survey. Sci. Hort. 11(4):303-317.

Kapłan, M. 2010. Effect of growth regulators on the branching ability of maiden apple trees of the 'Šampion' and 'Jonica' cultivars. Folia Hort. 22(2):3-7.

Keever, G.J., W. Foster, J. Olive, and M.S. West. 1993. Increasing 'Bradford' pear crotch angles and lateral shoot counts with benzyladenine or promalin sprays. HortScience 28:678.

McArtney, S. and J.D. Obermiller. 2015. Effect of notching, 6-benzyladenine, and 6-benzyladenine plus gibberellin $\mathrm{A}_{4}+\mathrm{A}_{7}$ on budbreak and shoot development from paradormant buds on the leader of young apple trees. HortTechnology 25:233-237.
McArtney, S.J. and S.-H. Li. 1998. Selective inhibition of flowering on 'Braeburn' apple trees with gibberellins. HortScience 33:699-700.

Miller, S.S. and B.J. Eldridge. 1986. Use of 6benzylamino purine and Promalin for improved canopy development in selected apple cultivars. Sci. Hort. 28(4):355-368.

Miranda Sazo, M. and T.L. Robinson. 2011. The use of plant growth regulators for branching of nursery trees in NY state. New York Fruit Qrtly. 19(2):5-9.

Palmer, J.W., S.M. Seymour, and R. Diack. 2011. Feathering of 'Doyenne du Comice' pear in the nursery using repeat sprays of benzyladenine and gibberellins. Sci. Hort. 130(2):393-397.

Robinson, T. and W. Stiles. 1995. Maximizing the performance of young apple trees. New York Fruit Qrtly. 3(2):10-16.

Robinson, T.L. 2008. The evolution towards more competitive apple orchard systems in the USA Acta Hort. 772:491-500.

Robinson, T.L., B. Black, and W. Cowgil. 2014. Use of multiple applications of Maxcel and Promalin to produce feathered trees. Compact Fruit Tree 47(1):23-28.

Robinson, T.L., A.M. DeMarree, and S.A. Hoying. 2007. An economic comparison of five high density apple planting systems. Acta Hort. 732:481-489.

Unrath, C. and J. Whitworth. 1991. Suppression of apple bloom with gibberellin sprays. J. Hort. Sci. 66(2):155-157.

van den Berg, A. 2003. Certified nursery tree production in Holland. Compact Fruit Tree 36(2):43-45.

Vanneste, J.L. 2000. Fire blight: The disease and its causative agent, Erwinia amylovora. CABI, Wallingford, UK.

Weis, H. 2004. Characteristics of the ideal nursery tree and its advantages in the orchard. Compact Fruit Tree 37(1):23-25.

Wertheim, S. 1978. Induction of side-shoot formation in the fruit-tree nursery. Acta Hort. 80:49-54.

Wertheim, S. and A.D. Webster. 2003. Propagation and nursery tree quality, p. 125-151. In: D. Ferree and I. Warrington (eds.). Apples: Botany, production and uses. CABI, Wallingford, UK. 